\title{
Jumboism and Jurisprudence: The Theory and Practice of Precedent in the Large Appellate Court $\dagger$
}

\author{
Arthur D. Hellmant†
}

It is our considered conclusion that the Fifth Circuit is geographically too large and that 15 judges is definitely six too many. ... Moreover, it is only natural that intracircuit conflicts multiply when there are 15 active judges. . . . Jumboism has no place in the Federal Court Appellate System. -Statement by eight judges of the former Fifth Circuit to the Commission on Revision of the Federal Court Appellate System (1973). ${ }^{1}$

In the founding years of the American republic, Congress established a two-tier structure for the federal judiciary, a structure that remained in place for more than a century. ${ }^{2}$ Change finally came in 1891 with the passage of the Evarts Act, which added a third tier by creating courts of appeals intermediate between the trial courts and the Supreme Court. Today, after the passage of another century, prominent voices suggest that a "crisis of volume" in the appellate courts requires another major restructuring of the

† Copyright 1989 Arthur D. Hellman.

t† Professor of Law, University of Pittsburgh. B.A., Harvard University, 1963; J.D., Yale Law School, 1966. This article is based on research undertaken for a forthcoming book, Arthur D. Hellman, ed, Justice Restructured: The Innovations of the Ninth Circuit and the Future of the Federal Courts (Cornell, forthcoming 1990). The research was supported by a grant from the United States Court of Appeals for the Ninth Circuit; however, the views expressed are the author's and do not necessarily reflect those of the court or any of its judges. The author acknowledges the research assistance of John Fielding, Gary Lynch, and Pamina Ewing, students at the University of Pittsburgh School of Law.

1 Commission on Revision of the Federal Court Appellate System, Hearings First Phase at 392-93 (GPO, 1973). See Deborah J. Barrow and Thomas G. Walker, A Court Divided 166-67 (Yale, 1988).

2 The Judiciary Act of 1789 actually created three sets of courts-district courts, circuit courts, and the Supreme Court-but the circuit courts were authorized to review district court decisions only in limited classes of cases. Felix Frankfurter and James M. Landis, The Business of the Supreme Court 12 (Macmillan, 1928). Moreover, the appellate function of the circuit courts soon atrophied, in large part because Congress did not provide those courts with separate judges. Id at $32,69,87$. Thus " $[t]$ he district and circuit courts were in practice two nisi prius courts dealing with different items of litigation." Id at 13. 
federal judicial system.

The perception of the inadequacy of the present arrangements rests in part on a fundamental change in the role performed by the courts of appeals. During the first several decades under the Evarts Act, those courts were confined largely to the task of review for error. The institutional functions of appellate review-declaring and harmonizing general principles-remained in the domain of the Supreme Court. If that model were still valid, the problem of appellate overload could be dealt with fairly easily through the creation of new geographically organized appellate courts. But geometric increases in caseload and the vast expansion in the scope of federal law have made that model obsolete. On many issues, especially outside the realm of constitutional adjudication, the governing law is the law of the circuit. As a result, geographic fragmentation would only add to uncertainty and disarray. Creation of new courts of national jurisdiction might solve the problem of "appellate capacity", but at great cost. If an additional tier of review were interposed between the Supreme Court and the regional circuits, the effect would be to increase the delay and expense of litigation. ${ }^{3}$ If, instead, new courts were organized by subject matter, jurisdictional disputes between courts of equal rank would arise, ${ }^{4}$ and the law would be removed from the hands of generalist judges appointed after scrutiny by the legal community as a whole. ${ }^{5}$

Against this background, the possibility of simply allowing existing circuits to grow (or even consolidating contiguous circuits) holds considerable promise. But the desirability of this approach depends on the soundness of the underlying premise: that adjudicative unity over a wider geographic area will bring coherence and consistency to the law without requiring additional institutions of review at the national level. If this premise is not sound, we would

${ }^{3}$ See, for example, Edward J. Horowitz and Michael J. Poster, The Proposed Panel to Resolve Intercircuit Conflicts: A Brief View from the Litigant's Perspective, 11 Hastings Const L Q 371 (1984). Establishment of an auxiliary court such as the proposed Intercircuit Tribunal would also entail less tangible costs. See Arthur D. Hellman, Caseload, Conflicts, and Decisional Capacity: Does the Supreme Court Need Help? 67 Judicature 28, 40-43 (1983) (noting consequences of Supreme Court's delegating statutory cases to a new court).

4 See Christianson v Colt Industries Operating Corp., 108 S Ct 2166, 2178 (1988) (Situations where "litigants are bandied back and forth helplessly between two courts . . . inhere in the very nature of jurisdictional lines, for as our cases aptly illustrate, few jurisdictional lines can be so finely drawn as to leave no room for disagreement on close cases."); Smith $v$ Orr, 855 F2d 1544 (Fed Cir 1988) (judges disagree over whether Federal Circuit has exclusive appellate jurisdiction to determine basis of jurisdiction in district court).

- For further discussion of the drawbacks of specialized appellate courts, see Richard A. Posner, The Federal Courts: Crisis and Reform 147-60 (Harvard, 1985); Arthur D. Hellman, Courting Disaster, 39 Stan L Rev 297, 308-10 (1986). 
simply be trading intercircuit conflict for intracircuit conflict-a much more pernicious phenomenon.

The Ninth Circuit as it has existed for the past nine years provides a unique testing ground for the large circuit model. ${ }^{6}$ The Ninth Circuit extends over nine states and two territories, and generates almost one-sixth of all appeals in the twelve regional circuits. In a single year, the court of appeals will adjudicate nearly 2,500 cases and will publish as many as 900 precedential opinions. ${ }^{7}$ The decisions are made by twenty-five active judges, ${ }^{8}$ ten senior judges, and a long parade of visiting judges-almost invariably sitting in panels of three. The court of appeals has embarked on an ambitious program to maintain consistency in its decisions, but among lawyers and district judges, the perception is widespread that inconsistency remains a major problem. ${ }^{8}$ If that perception is correct, the idea of the large circuit, however attractive in theory, may be doomed in practice. ${ }^{10}$ This article will address the question whether the Ninth Circuit Court of Appeals has succeeded in maintaining consistency in the law of the circuit.. ${ }^{11}$

- For an earlier study examining the subject from the perspective of the Ninth Circuit's judges, see Stephen L. Wasby, Inconsistency in the United States Courts of Appeals: Dimensions and Mechanisms for Resolution, 32 Vand L Rev 1343 (1979). At the time of Professor Wasby's study the Ninth Circuit Court of Appeals had only eleven active judges. Id at $1345 \mathrm{n} 6$. On the other hand, the conflict-avoidance mechanisms described in section I of this article were in their infancy.

71988 Annual Report of the Director of the Administrative Office of the U.S. Courts, Appendix I, 4-5.

${ }^{8}$ From 1980 through 1984 the Ninth Circuit had a full complement of twenty-three active judges. Legislation in 1984 increased the number of authorized judgeships to twenty eight, but because of departures from the bench and controversy over proposed nominations the court had no more than 26 active judges for most of the period from 1984 through the end of 1988. See Bankruptcy Amendments and Federal Judgeship Act of 1984, 28 USC § 44 (1982 \& Supp 1986).

- For example, in 1987 the Circuit Executive's Office conducted a survey of lawyers and district judges in the Ninth Circuit. Both groups were asked if they agreed with the statement, "There is consistency between [Ninth Circuit] panels considering the same issue." Fifty-nine percent of attorneys and 24 percent of district judges disagreed, and 18 percent of attorneys and 24 percent of district judges disagreed strongly. Ninth Circuit Judicial Council, Survey of District Judges and Attorneys Regarding the U.S. Court of Appeals for the Ninth Circuit 19 (July, 1987).

As this article was going to press, seven senators from Northwestern states introduced a new bill to divide the Ninth Circuit. S 948, 101st Cong, 1st Sess (1989). They relied heavily on the argument that the large size of the present circuit had led to inconsistencies in the law. See 135 Cong Rec S5026 (statement of Senator Gorton) and S5027 (statement of Senator Hatfield) (May 9, 1989).

${ }^{10}$ The conclusion does not necessarily follow. Any solution, whether it involves creation of new structures or improving present arrangements, will require tradeoffs among imperfect systems. See section IV.

1 The article is based in part on interviews with Ninth Circuit judges and on internal 
The article is divided into four sections. Section I sets forth the underlying premises and describes the procedures adopted by the Ninth Circuit to avoid inconsistencies among panel decisions. Section II develops a theory of intracircuit conflict through extrapolation from basic principles of precedent in a common law system. Section III reports the results of an empirical study applying the theory to measure the extent of inconsistency in the Ninth Circuit. Section IV considers the implications of the study for the workability of the large circuit and poses questions for further research.

At the cost of spoiling the suspense, it may be useful to summarize the findings of the empirical study. On the basis of an admittedly limited sample, it does not appear that intracircuit inconsistency is as much of a problem as many lawyers think. Head on conflicts are quite rare. Disarray caused by the existence of a large number of precedents pointing in different directions is more common, but seldom involves issues that directly affect primary activity.

\section{The Experience of the Ninth Circuit}

\section{A. The Large Court and the Problem of Inconsistency}

Underlying this study is the premise that a high degree of consistency and predictability in the law is necessary to the successful operation of the legal system. I hope that this is self-evident, but at the risk of reiterating the obvious, I begin by noting the principal concerns that underlie the premise. First, the ideal of equality is violated when similarly situated persons receive disparate treatment because two courts (or two panels of the same court) have attached different legal consequences to facts that are identical in all relevant respects. Second, uncertainty about what the law requires or permits will encourage wasteful litigation; and where litigation cannot be avoided, the existence of apparently inconsistent appellate decisions will add to the costs and other burdens of court proceedings. Third, intelligent planning and structuring of transactions will be frustrated when the relevant precedents in the governing jurisdiction give conflicting guidance on what the law is.

The values underlying these concerns are far more seriously threatened by conflicts within a circuit than by conflicts between

court documents made available to me on the understanding that they would not be quoted or cited directly. Statements about court practices or judges' views not otherwise attributed are drawn from these materials. 
circuits. If a district judge finds apparently conflicting authority from outside his circuit, he can ignore it, but if decisions within the circuit point in different directions, he must do his best to reconcile them. Similarly, a lawyer seeking to advise a client generally need not worry if another circuit has laid down a different rule, but if the apparently inconsistent holdings come from his own circuit, he ignores them at his peril. ${ }^{12}$

In theory, a large number of judges and the fact that decisions are made by panels of three should have no effect on the consistency of the law of the circuit. The reason is that all of the courts of appeals are committed to the rule of intracircuit stare decisis: panel decisions are binding upon subsequent panels unless overruled by the court en banc. ${ }^{13}$

Yet experience tells us that the formal rule of stare decisis does not necessarily guarantee consistency within a jurisdiction. Indeed, one school of thought, generally associated with the "Realist" movement, holds that "sufficient precedents, some conflicting and many intersecting at various angles, exist so that an appellate judge can rationalize from precedent or written law a result" actually determined by the judge's own predilections. ${ }^{14} \mathrm{I}$ agree with Professor Schauer that to regard this "as an accurate generalization of all or even most judicial decisions" is "at least erroneous and at times preposterous." At the same time, it would be naive

12 The intercircuit/intracircuit distinction is not always dispositive, even where criminal penalties are involved. The Supreme Court sees no unfairness in convicting a defendant under an interpretation of a criminal statute rejected by the defendant's own circuit, as long as "the existence of conflicting cases from other Courts of Appeals [made a contrary decision by the Supreme Court] reasonably foreseeable." United States $v$ Rodgers, 466 US 475 , 484 (1984).

${ }^{13}$ See, for example, Aetna Life Ins. Co. $v$ Alla Medical Services, Inc., 855 F2d 1470, 1473 (9th Cir 1988). There are two narrow exceptions to this rule. Later panels are not obliged to follow decisions that are found to be inconsistent with intervening Supreme Court rulings. See LeVick v Skaggs Cos., 701 F2d 777, 778 (9th Cir 1983). And in labor cases panels are permitted to repudiate circuit precedent and adopt the NLRB's contrary interpretation of the labor laws, but only if "the precedent constituted deferential review of NLRB decisionmaking." Mesa Verde Const. Co. v Northern Calif. District Council of Laborers, 861 F2d 1124, 1136 (9th Cir 1988) (en banc).

In some circuits, a subsequent panel is permitted to overrule an earlier decision if the proposed opinion is circulated to the full court and the other judges agree (or do not vote for en banc rehearing). This procedure is sometimes referred to as a "mini en banc." See Steven Bennett and Christine Pembroke, "Mini" In Banc Proceedings: A Survey of Circuit Practices, 34 Cleve St L Rev 531 (1986). Occasional ad hoc attempts by individual Ninth Circuit panels to invoke this procedure have always been rebuffed.

${ }^{14}$ This is Professor Schauer's description. Frederick Schauer, Easy Cases, $58 \mathrm{~S}$ Cal L Rev 399, 410 (1985).

${ }^{18}$ Id at 411 (emphasis in original). 
not to recognize that there are cases in which the relevant legal materials could support more than one result. In that situation, the outcome may well depend on the identity of the judges assigned to the case. ${ }^{16}$ And intuition tells us that the larger the number of judges, the greater the odds that a later panel will reach a result that is apparently inconsistent with one or more precedents already on the books.

But is that intuition correct? After all, it can be argued that what makes for inconsistency is not a larger number of judges but the presence on a court of judges with widely different approaches to legal problems. In this view, a homogeneous bench of twentyeight is no more likely to issue inconsistent decisions than an equally homogeneous bench of twelve. Conversely, an ideologically divided court of twelve will be no less prone to inconsistency than an ideologically divided court of twenty-eight.

One answer to this argument is that inconsistency is more of a problem not because the large circuit has more judges but because it adjudicates more cases. This in turn means that a larger number of precedents will be relevant to any given controversy. At worst, one or more earlier cases will not be cited in the more recent decisions, thus leaving the relationship among them unclear. At best, the newer decisions will draw distinctions not easily applied by lawyers and lower courts.

A second response is that reconciliation of apparent inconsistencies through en banc hearings is a realistic possibility in the small circuit, but not in the large one. To be sure, Congress has authorized large circuits to commit the decision of en banc cases to panels smaller than the full court. ${ }^{17}$ But even where the court has taken advantage of that opportunity, as the Ninth Circuit has done, ${ }^{18}$ the decision to grant en banc review remains with the full court, and the task can be extremely time consuming. As a result, judges are not likely to call for a ballot unless they are convinced that the panel decision will cause great mischief. Minor inconsis-

16 Judge Frank H. Easterbrook has put it this way: "Precedent covers the major premise. But the mind-set of the judge governs the minor premise." Quoted in Linda Greenhouse, Precedent for Lower Courts: Tyrant or Teacher?, NY Times B7 (Jan 29, 1988). For a particularly dramatic illustration, see Hodge v Evans Financial Corp., 823 F2d 559, 571 (DC Cir 1987) (MacKinnon dissenting) (noting reversal of judgment originally reached by court after one panel member died and was replaced by another judge; new opinion generally follows earlier dissent). See generally Beatty $v$ Chesapeake Center, Inc., 835 F2d 71, 75 n 1 (4th Cir 1987) (en banc) (Murnaghan concurring).

${ }_{17}$ District and Circuit Judges-Appointments, 28 USC § 46(c) (1982). See Barrow and Walker, $A$ Court Divided at 215-17 (cited in note 1).

${ }^{18}$ Ninth Circuit Rule 35-3 (formerly Rule 25). 
tencies or less deeply objectionable departures from precedent will be allowed to go uncorrected.

\section{B. The Ninth Circuit and the En Banc Process}

The centrifugal tendencies inherent in a large court might be expected to have operated with particular force in the Ninth Circuit Court of Appeals during the 1980's. Throughout the 1970's the court was generally regarded as conservative. Starting in 1978, a massive infusion of Carter appointees dramatically shifted the balance to the left. ${ }^{19}$ Then, in 1984, liberal judges began to be replaced by Reagan appointees. It would hardly have been surprising if decisions of the early 1980's created apparent conflicts with earlier rulings, or if post-1984 decisions appeared to depart from the law laid down in the period of liberal dominance.

But all this is speculation. It does not negate the possibility that the Ninth Circuit has succeeded in minimizing inconsistency. Certainly the court has tried. Over the years, the court has authorized and implemented an elaborate series of mechanisms designed to maintain intracircuit uniformity. Through an inventory system using detailed issue identification codes, cases raising the same issue can be calendared before the same panel; where that is not possible, the different panels are informed of the pendency of the other cases. ${ }^{20}$ Under the court's internal rules, when identical issues are pending before two or more panels, "[t]he panel to whom the issue was first submitted has priority,"21 and other panels are required to defer or vacate submission so that they can follow the law established by the first panel. ${ }^{22}$ Staff attorneys examine opinions as they are filed and advise panels if they perceive conflicts. Non-panel judges who discern the seeds of confusion or disarray in a panel decision can call attention to the problem; their memo-

10 The shift was acknowledged by the chief judge of the circuit. "As a result of the [Carter appointments], a rather conservative court of appeals was converted into a rather liberal one." Annual Judicial Conference Second Judicial Circuit of the United States, 106 FRD 103, 161 (1984) (remarks of Chief Judge Browning).

${ }^{20}$ For a more extended description of the inventory system, see Arthur D. Hellman, Central Staff in Appellate Courts: The Experience of the Ninth Circuit, $68 \mathrm{Cal} \mathrm{L} \mathrm{Rev} \mathrm{937,}$ 957-64 (1980). As indicated in that article, I had a hand in devising the system. However, a decade has now passed since that experience, and I no longer speak from personal knowledge.

${ }^{21}$ United States Court of Appeals for the Ninth Circuit General Orders 4.1 (1987).

${ }^{22}$ Id. The rule now in force was not adopted until 1983. A similar rule was approved in August 1981 but rescinded a month later. The rule comes into play only when later panels know that the issue has previously been submitted to another panel. Absent that knowledge, the first opinion to be filed controls. 
randa, often circulated to the full court, may result in modification or clarification of an opinion, even after publication.

Notwithstanding the effort put into its conflict-avoidance mechanisms, the court of appeals has recognized that these devices will not be perfectly effective. Conflicts will still arise and the only remedy will be to invoke the drastic procedure of rehearing by an en banc panel. Study of the en banc process should therefore shed light on the extent and significance of intracircuit conflict in the Ninth Circuit. ${ }^{23}$

I have used the term "en banc process" rather than "en banc hearing" because there are really three levels of decision making. The first stage involves the determination whether to conduct a ballot on taking a case en banc. Any litigant may make the suggestion, but a vote is taken only if one or more judges request it. Second, there is the vote itself and the exchange of memoranda that precedes it. At that stage all active judges are eligible to participate, and if a majority of the nonrecused judges vote in the affirmative the case will be heard en banc. Finally there is the en banc court itself. In the Ninth Circuit, that consists of eleven judges: the chief judge and ten other judges selected at random.

For purposes of the study, I was allowed to read the memoranda exchanged by the judges in the course of deciding whether to grant en banc review during the years 1981 through 1986. I used those memoranda to identify the issues that were thought to require en banc resolution and the reasons one or more judges believed en banc review was necessary. As a condition of gaining access to this material, I agreed not to quote from the memoranda in a way that would identify particular cases or to attribute positions to individual judges. The reader will have to take on faith the accuracy of my characterizations.

The first and most important finding is that en banc ballots were rarely requested and even more rarely successful. In the six years of the study there were fewer than 160 cases in which a judge called for a vote on en banc rehearing. ${ }^{24}$ Less than one-third of

${ }^{23}$ The description and analysis in this section are based on the more detailed study in Arthur D. Hellman, Maintaining Consistency in the Law of the Large Circuit, in Arthur D. Hellman, ed, Justice Restructured: The Innovations of the Ninth Circuit and the Future of the Federal Courts (Cornell, forthcoming 1990).

24 The figures given in this section are not exact, partly because the court kept no single comprehensive list of en banc calls during this period. My own list was compiled from two others, and it is possible that a case here and there slipped through the cracks. Moreover, the files of the cases I did study were not necessarily complete, and missing memoranda might well have caused me to modify some of my characterizations. 
those cases-forty nine in all-were actually heard en banc. In that same period, the court adjudicated more than 12,000 cases, 5,000 of which received published opinions. ${ }^{25}$ This means that en banc decisions accounted for less than 1 percent of the court's precedential rulings.

The raw figures alone thus suggest that en banc hearings played only a minor role in maintaining consistency in the law of the circuit. Scrutiny of the opinions and internal memoranda strongly reinforces that conclusion. More than half of the en banc requests made no assertion at all that the panel decision created an intracircuit conflict. These non-conflict cases were a varied lot. In some, the memoranda emphasized the precedential significance of the panel's decision. ${ }^{26}$ In others, the judges pointed to the number of people who would be affected, ${ }^{27}$ the likelihood that the Supreme Court would grant review, ${ }^{28}$ or simply the egregiousness of the panel's error. ${ }^{29}$ The common thread was the absence of any suggestion that the panel decision posed a threat to uniformity within the circuit.

This leaves barely seventy-five cases in six years in which a judge requested en banc hearing to resolve an intracircuit conflict. But even that figure overstates the role of conflict resolution in the en banc process. In more than one-quarter of the cases that I have classified as involving claims of conflict, concerns about inconsis-

${ }^{25}$ Adjudicated cases are defined as cases disposed of after oral argument or submission on briefs. Excluding consolidated cases, these totalled 12,698 during the six years of the study period. The number of such cases receiving published opinions was 5,004. These figures have been extracted from the Ninth Circuit's operational database ARMS through the courtesy of the Clerk of Court, Cathy A. Catterson.

${ }^{28}$ Illustrations of this pattern can be seen in published dissents from denial of rehearing en banc. See, for example, Miller v Rumsfeld, 647 F2d 80, 90 (9th Cir 1981) (Norris dissenting); California State Council of Carpenters v Associated General Contractors, 648 F2d 527, 545 (9th Cir 1981) (Sneed dissenting), rev'd 459 US 519 (1983); International Olympic Committee v San Francisco Arts and Athletics, 789 F2d 1319, 1326 (9th Cir 1986) (Kozinski dissenting), aff'd, 483 US 522 (1987); Golden Eagle Distributing Corp. $v$ Burroughs Corp., 809 F2d 584 (9th Cir 1987) (Noonan dissenting).

${ }_{27}$ See, for example, United States v Harvey, 711 F2d 144, 145 (9th Cir 1983) (Kennedy dissenting from denial of rehearing en banc).

${ }^{28}$ Some of the panel decisions that were vacated by the grant of en banc review would have come within the Supreme Court's then obligatory jurisdiction. See, for example, United States v Flores, 729 F2d 593 (9th Cir 1983) (holding federal statute unconstitutional), rev'd, 753 F2d 1499 (9th Cir 1985) (en banc); United Farm Workers v Arizona Agricultural Employment Bd., 696 F2d 1216 (advance sheet) (9th Cir 1983) (opinion withdrawn from publication) (holding state statute unconstitutional), rev'd, 727 F2d 1475 (9th Cir 1984) (en banc).

28 See, for example, Students of California School for the Blind $v$ Honig, 745 F2d 582 (9th Cir 1984) (Sneed dissenting), vacated, 471 US 148 (1985). 
tency were clearly secondary to other reasons for questioning the panel decision. For example, in one criminal case the en banc process was initiated by a lengthy and passionate memorandum that concentrated on the merits without even mentioning the precedent that later emerged as the basis for an almost tangential assertion of conflict. In at least two of the "conflict" cases that did receive en banc consideration, the en banc opinion made no mention of the allegedly inconsistent decisions.

En banc requests that claimed intracircuit conflicts had about the same success rate as en banc requests generally: one in three (approximately twenty-five cases). However, fewer than twenty of these cases generated an en banc decision that actually resolved a conflict. ${ }^{30}$ In addition, three requests led panels to change the result of published dispositions, after which the requests were withdrawn. In about a dozen other cases the panel amended the opinion without changing the result; with two exceptions the modifications did not satisfy the requesting judge. Overall, there were no more than thirty cases in six years in which the en banc process led to the reversal or overruling of a decision asserted to be in conflict with another precedent. ${ }^{31}$

The conclusion is inescapable: en banc decisions contributed only minimally to the preservation of uniformity in the law of the Ninth Circuit. The significance of this finding is not so clear, however. One possible explanation is that notwithstanding the large number of judges and the widely perceived ideological division within the court, there simply were not very many intracircuit conflicts. Perhaps the mere availability of en banc review served as a restraint on the three-judge panels; perhaps the judges truly internalized a commitment to consistency.

The other possible explanation is that conflicts proliferated during the period of the study without giving rise to en banc requests. Perhaps the three-judge panels were more concerned about reaching "correct" results in individual cases than about maintain-

${ }^{30}$ An en banc decision was counted as having resolved a conflict if it overruled a precedent that the judges viewed as inconsistent with other Ninth Circuit cases or if it reversed the original panel and cited with approval an earlier ruling that was said to be in conflict with the panel decision.

31 This tally does not include the seven cases in which an en banc ballot was triggered by the recognition that two panels that were considering similar issues at the same time were prepared to reach different results. In voting on these cases, the judges appear to have assumed that if en banc review was denied, one panel would back off, so no conflict would result. That is exactly what happened in the three cases where the request failed to gain a majority. 
ing consistency between cases, and non-panel judges took an extremely tolerant view of what constitutes a conflict. More plausibly-and of particular significance in the present context-the judges may have acted on a shared sense that the court could not increase its en banc activity in any significant measure without impinging dangerously on the time available for panel dispositions.

The data on the en banc process do not permit us to choose between these explanations. The question remains: does the paucity of en banc hearings reflect a low incidence of conflict, or were the judges unwilling or unable to use the en banc process to resolve conflicts that did occur? Phrased thus, the formulation sounds like a cue for another empirical study-a study not limited to en banc requests. And so it is. But more than empiricism is involved. Scholars, lawyers, and judges have struggled for years to answer the question "What is a conflict between circuits?"32 The inquiry is no less difficult when the search is for conflicts within the circuit. Thus, before one can investigate the success of the Ninth Circuit's efforts, it is necessary to establish a conceptual framework for analyzing inconsistency in the law. To that task I now turn. ${ }^{33}$

\section{The Nature of Intracircuit Conflict}

\section{A. The Jurisprudential Context}

The starting point for any conceptualization of intracircuit conflict must be the common law system of precedent. ${ }^{34}$ Under that system, the binding effect of a decision is limited to those points that the court necessarily decided; moreover, the determination of what was "necessary" is made not by the authoring court, but by subsequent cases. $^{35}$ Over a period of time, broad propositions will be narrowed or restated with qualifications; dicta (supportive or oppositive) will be elevated to holdings; emphasis will

${ }^{32}$ See Arthur D. Hellman, Error Correction, Lawmaking, and the Supreme Court's Exercise of Discretionary Review, 44 U Pitt L Rev 795, 868 n 374 (1983) (giving illustrations).

${ }^{33}$ This article addresses the problem of inconsistency within a single court or jurisdiction. Different considerations come into play when the task is to identify conflicts between courts of equal rank whose decisions are not binding upon one another. See Arthur D. Hellman, The Proposed Intercircuit Tribunal: Do We Need It? Will It Work?, 11 Hastings Const L Q 375, 393-94 n 88 (1984).

${ }^{34}$ The classic descriptions of that system are found in the works of Karl Llewellyn. Karl N. Llewellyn, The Common Law Tradition: Deciding Appeals 75-99 and passim (Little, Brown, 1960); Karl N. Llewellyn, The Bramble Bush 64-69 (Oceana, 1960).

ss Not everyone accepts this proposition, although it is part of the classical theory and contributes significantly to the legitimacy of judicial lawmaking. For further discussion, see section II.B.3. 
shift from one argument or ground of decision to another. In short, the law evolves from case to case, moving first one way, then the other, in a process that can aptly be called dialectical, a process in which a certain tension is inherent. How then does one distinguish the decision that creates an intracircuit conflict from the decision that merely represents another stage in the evolution of the law, another step in the dialectic?

When I first considered the problem of intracircuit disarray, it seemed to me that a good starting point for analysis was Judge Cardozo's often quoted tripartite typology of appellate cases:

[A] majority [of cases] . . . could not, with semblance of reason, be decided in any way but one. The law and its application alike are plain. ... In another and considerable percentage, the rule of law is certain, and the application alone doubtful. . . . Finally there remains a percentage, not large indeed, and yet not so small as to be negligible, where a decision one way or the other, will count for the future, will advance or retard, sometimes much, sometimes little, the development of the law. ${ }^{36}$

But after attempting to apply Judge Cardozo's classification scheme to some Ninth Circuit decisions, I became convinced that whatever its value for other purposes, it offered little promise for identifying the cases that are likely to generate disarray or uncertainty in the law. A different approach, designed specifically for an intermediate appellate court in the federal system, was necessary. Substantially aided by discussions with members of the court, I have constructed a hypothesis that I think serves the purpose.

The hypothesis consists of three sequential propositions, each of which addresses one of the possible relationships between a particular new decision and existing law in the circuit. First, if losing counsel cannot point to relevant circuit precedents that reach results different from the panel's result in the case being considered, there is no possibility of conflict or uncertainty of the kind that arouses legitimate concern among judges and lawyers. Second, the cases that offer the greatest potential for conflict are those in which the panel distinguishes a circuit precedent that losing counsel has reasonably relied on as requiring (not simply supporting) a different result. Third, to the extent that the distinctions drawn by the later panel are clear and cogent, the potential for disarray is not likely to be realized.

${ }^{36}$ Benjamin N. Cardozo, The Nature of the Judicial Process 164-65 (Yale, 1921). 
This formulation, I believe, will go far to assist in identifying intracircuit conflicts and in distinguishing conflicts from the evolutionary shifts inherent in a common law system. However, the formulation does not fully address two precedential patterns that may create disarray in the law of the circuit. First, a panel may simply fail to cite a precedent that has reached an opposite result on facts that appear to be similar in all relevant respects. The effect is to make it impossible to carry out the third step of the analysis. Second, the three-step approach does not fit well with situations where the governing legal rules turn on highly particularized determinations and the number of reported decisions is large.

I shall have something to say about both of these patterns, but the principal thrust of this section will be to elucidate the formulation I have suggested. To do so, I shall proceed step by step through the analysis it contemplates and explain the rationale underlying each element. Before turning to that inquiry, however, I must note two categories of cases that appear to pose little if any risk of creating disuniformity within the circuit.

The first derives from Judge Cardozo's analysis. Cardozo began with the observation that the vast majority of cases in his court (the New York Court of Appeals) could be decided only one way, since "the law and its application alike are plain."s7 Distinguished circuit judges have echoed this thought as applied to the federal courts of appeals in more recent times. ${ }^{38}$ For convenience, cases in this group will be referred to as "easy cases."

A case may be "easy" for a number of reasons. Here are some of the more common patterns.

- The legal rules are undisputed, and the appellant challenges only factual findings that are not clearly erroneous or a jury verdict that is supported by substantial evidence.

- The only issues involve trial or pretrial rulings reviewed for abuse of discretion, and the trial court clearly acted within the allowable range.

- The case falls squarely within recent precedent of the Su-

37 Id at 164.

ss See, for example, Alvin B. Rubin, Does Law Matter? A Judge's Response to the Critical Legal Studies Movement, 37 J Legal Educ 307, 310 (1987); Henry J. Friendly, Reactions of a Lawyer-Newly Become Judge, 71 Yale L J 218, 222 (1961). Judge Harry T. Edwards of the D.C. Circuit has estimated that approximately one-half of the cases he hears each year are "easy" in the sense that "the pertinent legal rules seem . . . unambiguous and their application to the facts appears clear." Harry T. Edwards, The Role of a Judge in Modern Society: Some Reflections on Current Practice in Federal Appellate Adjudication, 32 Cleve St L Rev 385, 389-90 (1983-84). 


\section{preme Court or the Ninth Circuit.}

- The plaintiff sought to invoke a federal cause of action that plainly did not cover his grievance, and the trial court properly dismissed the suit or granted summary judgment for the defendant. $^{39}$

I suggest that, almost by definition, easy cases can pose no threat to consistency in the law. But it is unnecessary to test the validity of this hypothesis as a jurisprudential matter. In the Ninth Circuit today, as in all of the circuits, cases of this kind will generally be decided by opinions designated as "not for publication." Under court rules, unpublished opinions have no precedential value and cannot be cited to or by courts within the circuit. ${ }^{40} \mathrm{~A}$ case that has no precedential value cannot give rise to an intracircuit conflict, or more accurately cannot create a conflict that will generate uncertainty or inconsistency in the law of the circuit.41

This does not mean that unpublished opinions have no relevance to the study. For one thing, these cases include at least some that could not be characterized as easy. ${ }^{42}$ If a case is not easy, the reason may be that the law is unclear. ${ }^{43}$ In a similar vein, apparent inconsistencies among unpublished dispositions may furnish evidence of uncertainty or disarray created by published decisions. But in seeking the sources of inconsistency, we can omit the unpublished opinions altogether. That is no small step; in recent years, substantially more than half of the court's cases have been decided by unpublished opinions. ${ }^{44}$

30 See, for example, Learned $v$ City of Bellevue, 860 F2d 928 (9th Cir 1988).

10 See, for example, Ninth Circuit Rule 36-3.

11 See Klein v Stop-N-Go, 824 F2d 453, 453 (6th Cir 1987) (Krupansky dissenting) ("[T]he majority seeks to avoid a direct intracircuit conflict with existing reported legal precedent within this circuit . . . by resorting to an unpublished disposition.").

${ }^{42}$ See, for example, Rodriguez-Guillen v INS, No 86-7111 (9th Cir, Sept 4, 1987) (panel divided on whether alien satisfied requirements of regulation governing motions to reopen deportation proceedings); United States v Taylor, No 86-5092 (9th Cir, Aug 18, 1987) (panel divided on evidentiary ruling in criminal case); United States v Spies, No 85-3177 (9th Cir, June 12, 1987) (court finds search warrant invalid, but holds evidence admissible because officers acted in good faith); Vaca-Contreras $v$ INS, No 86-7617 (9th Cir, June 16, 1987) (panel divided on whether agency abused discretion in denying suspension of deportation on ground of extreme hardship).

43 Of course, there may be other reasons. See, for example, United States v Kamel, No 85-5016, slip op at 16 (9th Cir, Sept 2, 1987) (noting that criminal trial "was hardly errorfree," but affirming conviction because "none of the errors brought to our attention merits reversal.").

44 The figures for the last six calendar years are as follows. 
Second, cases presenting only issues of state law are also unlikely to generate intracircuit disarray. This conclusion rests in part on the limited role of the federal courts in deciding issues of state law: rulings of the Ninth Circuit can be overridden by the state courts, and aberrant decisions are not likely to have a long life. But I also surmise that because of that limited role the court of appeals judges are less likely to draw debatable distinctions of the kind that cause difficulties for lawyers and lower courts. Consistent with this view, only one of the more than 150 cases in which Ninth Circuit judges called for en banc review in the years 1981 through 1986 involved issues of state law. ${ }^{45}$

\section{B. The Paradigm of the Intracircuit Conflict}

After excluding unpublished opinions and cases raising only issues of state law, we are left with cases presenting issues of federal law as to which it cannot be said that "the law and its application alike are plain." That description fits a large proportion of the court's cases, but if my hypothesis is correct, only a small percentage poses a real threat to consistency in the law of the circuit.

\section{Step one.}

In determining whether a new panel decision contains the seeds of intracircuit disarray, the threshold question is whether there is a relevant circuit precedent that reached a different result. A precedent is "relevant" in this sense if a reasonable lawyer would invoke it as supporting a legal argument on a disputed proposition in the case. ${ }^{46}$ The "result" is "different" if, on the issue being considered, the earlier court ruled against the interest or claim that prevailed in the later case or vice versa. For example, Russo $v$ Matson Nav. Co. ${ }^{47}$ reached a "different result" from Folkestad $v$ Burlington Northern, Inc., ${ }^{48}$ because Russo denied a setoff to a defendant railroad in an FELA case while Folkestad

\begin{tabular}{llll}
\hline & $717(36 \%)$ & $1280(64 \%)$ & 1997 \\
1984 & $829(40 \%)$ & $1220(60 \%)$ & 2049 \\
1986 & $946(42 \%)$ & $1328(58 \%)$ & 2274 \\
1987 & $938(41 \%)$ & $1362(59 \%)$ & 2300 \\
1988 & $829(39 \%)$ & $1287(61 \%)$ & 2116
\end{tabular}

These figures have been supplied by Clerk of the Court, Cathy A. Catterson.

${ }^{26}$ This was one of the findings of the study of en banc requests described in section $I$.

48 See Frederick Schauer, Precedent, 39 Stan L Rev 571, 576-79 (1987).

4786 F2d 1018 (9th Cir 1973).

48813 F2d 1377 (9th Cir 1987). 
allowed it. Similarly, Sierra Club v Union Oil Co.49 reached a "different result" from Marathon Oil Co. $v$ EPA, ${ }^{50}$ because Union Oil disallowed an "upset defense" in a citizen enforcement proceeding under the water pollution act, while Marathon permitted it.

The premise of this first step is that conflict or uncertainty of the kind that concerns us here can exist only if two or more precedents addressing the same legal problem have reached results that are different in the sense that I have described. ${ }^{51}$ Thus, if the question is whether to give effect to an alleged oral modification of employee benefit provisions in a collective bargaining agreement, and the cases in which the defense was raised have all insisted that modifications be in writing, there can be no conflict, because all of the relevant law points in the same direction. ${ }^{\mathbf{5 2}}$ So, too, if all circuit precedents have rejected claims that a narcotics sentence was so disproportionate to the offense as to violate the Eighth Amendment. ${ }^{63}$

Under this view, it is immaterial that losing counsel in the later case sought to distinguish the earlier decision, or that the distinctions offered might have been persuasive to other judges. Even if the new decision changes the law by expanding the reach of an existing line of cases, it will create no conflict as long as there are no precedents that point in the opposite direction. For example, in Phillips $v$ Amoco Trinidad Oil Co., ${ }^{54}$ the court held that foreign

49813 F2d 1480 (9th Cir 1987).

so 564 F2d 1253 (9th Cir 1977).

B1 Usually it will be obvious whether the "result" of an earlier case is "different," but in two situations the concept is ambiguous. Sometimes a litigant will invoke an argument that is identical to one used against his counterpart in the earlier suit. See, for example, Lyle $v$ Secretary of HHS, 700 F2d 566 (9th Cir 1983). Should the "result" be identified by reference to the party or to the argument? A narrower problem arises in decisions reviewing orders of agencies like the National Labor Relations Board: should the result turn on whether the agency won or lost, or on whether the underlying claim was accepted or rejected?

In both situations, the most sensible approach will generally be to treat the earlier decision as reaching a different result if the outcome was different in either of these respects. The inquiry then moves to the second step of the analysis. At that stage the difference in procedural posture-apart from other possible distinctions-will usually lead to the conclusion that the earlier decision was only a supporting precedent for the losing party in the later case. See section III.

${ }^{82}$ See, for example, Pierce County Hotel and Restaurant Employees v Elks Lodge, 827 F2d 1324, 1328 (9th Cir 1987); Operating Engineers Pension Trust v Giorgi, 788 F2d 620, 623 (9th Cir 1986) (Kozinski concurring). See also 134 Cong Rec S16100 (Oct 14, 1988) (remarks of Sen. Hatch) (citing case settled out of court in apparent reliance on circuit precedents).

${ }^{63}$ See, for example, United States v Klein, 860 F2d 1489, 1496-99 (9th Cir 1988); United States v Cook, 859 F2d 777, 778-79 (9th Cir 1988).

s4 632 F2d 82 (9th Cir 1980). 
seamen could not bring an action under the Jones Act for injuries arising out of the operation of an American-owned, American-flagged oil drilling vessel stationed in another country's territorial waters. Plaintiffs in a later case, Zipfel $v$ Halliburton Co. ${ }^{\text {s6 }}$ argued that the Phillips rule applies only to stationary drilling rigs, not to floating vessels. The court rejected the argument, thus expanding the application of Phillips. Because both decisions rejected the foreign seamen's claims, there can be no conflict between them.

Nor can a conflict be created by a later court's use of different language or reasoning from that of an earlier opinion. Anything the later court might say that would point to a different result in a third (hypothetical) case can be at best dictum. Even if the variation in approach engenders some doubt as to how broadly the rule of the first case will be applied, the law is no more uncertain than it was when only the first decision was on the books. In fact, the existence of multiple decisions may help lawyers and district courts to predict the future course of the law.

The point is illustrated by a pair of cases in which shipowners were asserting that an exculpatory clause in a pilotage tariff was an unenforceable contract of adhesion. In United States $v$ SS President Van Buren, ${ }^{58}$ the court rejected the claim, emphasizing that the pilotage scheme was voluntary and that the shipowner had the option of purchasing trip insurance at nominal cost. ${ }^{57} \mathrm{~A}$ decade later, in Guangco v Edward Shipping \& Mercantile, S.A., ${ }^{58}$ the court was confronted with a challenge to an exculpatory clause in a pilotage agreement that was not voluntary. Moreover, there was no indication that the shipowner had the option of purchasing insurance. The court upheld the exculpatory clause anyway, this time on the ground that the pilot, upon boarding the ship, came under the control of the shipowner, who thus bore the responsibility for his acts. ${ }^{59}$ Certainly the two opinions apply different criteria for determining whether an exculpatory clause will be enforced. And one can imagine a hypothetical third case in which the "free choice" approach and the "pilot's duties" approach, taken in isolation, might lead to different results. To that extent the second de-

ss 832 F2d 1477, 1482-83 (9th Cir 1987), cert denied 108 S Ct 2819 (1988), reh'g denied 109 S Ct 2 (1988), amended 861 F2d 565 (9th Cir 1988).

se 490 F2d 504 (9th Cir 1973).

${ }^{57}$ Id at 509. The major issue in the case was whether the pilotage scheme was indeed voluntary. See id at 506-07.

ss 705 F2d 360 (9th Cir 1983). This was one of the cases in the empirical study described in section III.

${ }^{59}$ Id at 362-63. 
cision created some uncertainty about where the law of the circuit might move in the future. But a more realistic view is that the first case rejected the unconscionability claim upon a finding of voluntary choice; the second case rejected the claim in a setting of compulsion. The later precedent thus gave no ground for predicting that the court would strike down an exculpatory clause under some other set of facts. By the same token, it created no conflict. ${ }^{60}$

More generally, the first step of the analysis rests on the view that dictum, especially dictum that points in the opposite direction from the holding, cannot give rise to an intracircuit conflict. ${ }^{61}$ Some lawyers and judges will regard this approach as unduly narrow, but I think it follows from basic doctrines of precedent. Consider, for example, two decisions on Indian tribal immunity handed down several weeks apart in 1985. In Hardin $v$ White Mountain Apache Tribe, ${ }^{62}$ the court, quoting a 1983 Ninth Circuit opinion, stated that tribal immunity is not a bar to "actions which allege conduct that is determined to be outside the scope of a tribe's sovereign powers."'63 However, in Chemehuevi Indian Tribe $v$ California State Board of Equalization, ${ }^{64}$ a different panel asserted that the statement in the 1983 opinion was erroneous and that a "tribe remains immune from suit regardless of any allegation that it acted beyond its authority or outside of its powers."65 Certainly these statements are squarely in conflict. But both 1985 cases, as well as the 1983 decision, ruled in favor of tribal immunity. A

${ }^{60}$ A similar analysis applies to United States $v$ Swacker, 628 F2d 1250 (9th Cir 1980), and United States v Moran, 759 F2d 777 (9th Cir 1985), two Ninth Circuit cases in which criminal defendants asserted that preindictment delay violated their right to due process. The two decisions were cited as an example of intracircuit conflict by a member of the Ninth Circuit Judicial Conference in response to a survey I conducted in late 1988. The reason, presumably, is that Swacker relied on the defendant's failure to show actual prejudice, Swacker, 628 F2d at 1254, while Moran required "some showing of governmental culpability," Moran, 759 F2d at 783. Thus, as with the exculpatory clause issue, one can imagine hypothetical cases in which the two approaches might lead to different results. But because both cases rejected the due process claim, the later decision did not create a conflict.

61 The discussion in the text assumes that the dictum is found in the earlier case, but the analysis would apply equally to dictum in the later decision. Dictum in the earlier case that supports the result will generally be tantamount to a broader or alternative rationale. If it is invoked by the losing party in the later case, that means that the two decisions reached contrary outcomes, thus implicating step two of the analysis.

${ }^{82} 761$ F2d 1285, opinion superceded by 779 F2d 476 (9th Cir 1985) (all references in text are to the first panel opinion).

${ }^{63} 761$ F2d at 1287, quoting Snow v Quinault Indian Nation, 709 F2d 1319, 1321 (9th Cir 1983).

64 757 F2d 1047 (9th Cir 1985), rev'd in part, 474 US 9 (1985).

es Id at 1052. 
plaintiff seeking to sue a tribe could point to no case in which the ultra vires exception had provided a basis for piercing the immunity. Thus, under my analysis, there was no conflict.

This conclusion may seem perverse, but it is justified by the different ways in which the inconsistent statements are used in the two opinions. In Chemehuevi, the repudiation of the ultra vires exception is essential to the court's holding; it is the basis on which the panel affirms the district court's dismissal of the state's counterclaim against the tribe. But in Hardin the endorsement of the exception can only be dictum. Far from being necessary to the result, ${ }^{66}$ it is actually in tension with it.

Adherence in this context to the distinction between holding and dictum is more than a matter of jurisprudential tidiness. In a democratic society, treating statements like the one in Hardin as non-binding dicta helps to confine the lawmaking powers of judges to the minimum necessary to serve the values underlying the doctrine of precedent. And from a utilitarian standpoint, statements unnecessary to the result are properly treated as dictum because of the high likelihood that they will not have received thorough consideration.

The Hardin case is a good illustration of the latter point. If the Hardin panel had been prepared to deny immunity to the tribe on the basis of the ultra vires exception, it would not have confined its analysis to a single sentence supported by a precedent in which the treatment of the issue was equally perfunctory (and equally unnecessary). The judges would have undertaken research that would undoubtedly have uncovered the Supreme Court precedents cited in Chemehuevi that cast grave doubt on the vitality of an ultra vires exception. If the point had not been adequately argued in the original briefs, a petition for rehearing would have called the panel's attention to the novel and controversial character of the holding. ${ }^{67}$ But because the statement in the actual decision did not affect the result, none of these things took place. And the rule of stare decisis should not have precluded later panels from consider-

ss In fact, the Hardin panel withdrew its original opinion and replaced it with one in which the discussion of the ultra vires exception had been excised. The new opinion is otherwise identical to the original one. See Hardin, 761 F2d at 1287, modified by 779 F2d at 478.

${ }^{87}$ In the actual case, it is hard to imagine why the tribe would have filed a petition for rehearing to correct an erroneous statement in the opinion when it had won unequivocally on the immunity issue and in the case as a whole. While the plaintiff would have had an incentive to seek rehearing, he would hardly have challenged the one statement in the opinion that favored his position. 
ing the question anew. ${ }^{68}$

I do not want to overstate the argument. If an oppositive dictum stands alone, or if it is reinforced by other dicta that suggest the same conclusion, lawyers and lower courts can properly treat it as an indication of the direction in which the law of the circuit might go. ${ }^{69}$ But if a later panel, in actually deciding the question, rejects the dictum, its holding will wipe out whatever precedential value the dictum might previously have had. For that reason the later decision will create no conflict. ${ }^{70}$

Conversely, if the later case does reach a result that is different in the sense I have described, the earlier precedent will be deemed "contrary" even though both decisions follow the same legal rule. For example, in Alaniz $v$ California Processors, Inc., ${ }^{71}$ the court adopted the rationale of Schaeffer $v$ San Diego Yellow Cabs, Inc. ${ }^{72}$ to determine whether an employer could be held liable for back pay under Title VII of the 1964 Civil Rights Act when the discrimination resulted from good faith reliance on a state protective statute. But because Schaeffer allowed back pay, while Alaniz denied it, Schaeffer is a contrary precedent for the later decision. Of course, in situations like this it is likely that the contrary prece-

${ }^{68}$ Different considerations apply in determining the extent to which lower courts are bound by dictum (whether supportive or oppositive) in Supreme Court decisions. See United States $v$ Underwood, 717 F2d 482, 484-86 (9th Cir 1983); National Audubon Soc'y v Department of Water, 869 F2d 1196, 1212 n 10 (9th Cir 1988) (Reinhardt dissenting). These cases are beyond the scope of this article.

${ }^{68}$ Ironically, if a later panel follows oppositive dictum in an earlier case, it too may be accused of creating a conflict because of the difference in results in the two cases.

70 The question arises as to whether the analysis in the text applies to situations in which the court of appeals finds error in a ruling of the trial court but holds the error to be harmless and affirms the judgment. At first blush, the answer is yes. Like the statement about ultra vires acts in Hardin, the finding of error is not only unnecessary to the result but in tension with it. By the panel's own accounting, the outcome would have been no different if the court, instead of deciding whether the trial court erred, simply assumed it. Compare, for example, United States $v$ Talley, 790 F2d 1468, 1469 (9th Cir 1986). Why should the judges be able to create binding precedent by addressing the merits of an issue that by their own admission is unnecessary to the resolution of the case? See United States $v$ Monaco, 735 F2d 1173, 1178 (9th Cir 1984) (Duniway concurring and dissenting).

If there is an answer to this argument, it must be sought in the policies underlying the harmless error rules. For example, if a holding of harmlessness were to deny precedential status to a finding of error, judges might change their behavior in either of two ways. They might be less inclined to find errors harmless, thus requiring unnecessary retrials. Or they might refrain from undertaking the inquiry into the claim of error, thus diminishing the ability of appellate courts to police compliance with the articulated rules. It also makes a difference whether one approaches the question at the start of the panel's deliberations or after it has reached its conclusion.

7785 F2d 1412 (9th Cir 1986).

${ }^{72} 462$ F2d 1002 (9th Cir 1972). 
dent will be only "supporting" for the losing party, and so it is here.

One other aspect of the first step deserves mention. When a case contains multiple issues and the holdings are either cumulative or independent, each must be considered separately in order to determine whether a conflict exists. For example, if a court permits an interlocutory appeal from a district court's rejection of an immunity defense, the ruling might conflict with a prior decision disallowing a similar appeal even if the later case rejects the defense on the merits. From the standpoint of lawyers and judges who want to know what the law is, different results on discrete issues are what count unless one of the determinations can properly be regarded as dictum.

\section{Step two.}

If there is a relevant circuit precedent that reached a contrary result, the next question is whether the precedent is one that losing counsel reasonably relied upon as requiring the same result. It is not enough that the earlier case is "relevant" in the broad sense contemplated by the first step, i.e., that the earlier case would support the holding sought by losing counsel. Rather, counsel must be able to assert, with strong support from the relevant legal materials, that any distinctions between the two cases are irrelevant as a matter of law.

Two aspects of this formulation require discussion: the distinction between a "supporting" precedent and a "compelling" one;" and the concept of "reasonable reliance" on a ruling distinguished by the later panel.

The distinction between "supporting" and "compelling" precedent is illustrated by a pair of recent cases involving issues of statutory construction. In United States $v$ Smith, ${ }^{74}$ the court held that photographic negatives portraying minors in sexually explicit poses were prohibited "visual depictions" under one criminal statute. Later, in United States $v$ Naaman, ${ }^{75}$ the court held that a

${ }^{73}$ The distinction, sometimes expressed in precisely this language, is not unfamiliar to lawyers and judges. See, for example, Monessen Southwestern Ry. Co. $v$ Morgan, $108 \mathrm{~S} \mathrm{Ct}$ 1837, 1852 (1988) (O'Connor dissenting) ("The majority does not, and I believe could not, say that the result reached today is compelled by those decisions."); USA Petroleum Co. $v$ Atlantic Richfield Co., 859 F2d 687, 702 (9th Cir 1988) (Alarcon dissenting) (citing "closest case to the facts presented here" as "instructive, but ... not controlling because it differs from the present case in several important respects").

74 795 F2d 841 (9th Cir 1986).

${ }^{75} 813$ F2d 1577 (9th Cir 1987). 
rubber stamp is not an "impression" within the meaning of another criminal statute. The government drew an analogy between the negatives in Smith and the stamps in Naaman, contending that both were a reverse image of the ultimate product. In that limited sense, Smith did support the government's position in Naaman. But the very fact that the government resorted to analogy confirms that it could not reasonably have argued that upholding the conviction in Smith required a similar result in Naaman. For that reason, Smith and Naaman can coexist without creating an intracircuit conflict.

In order for a precedent to be "arguably compelling," the decision must actually address the issue raised by the later case. For example, in Beisler $v$ Commissioner, ${ }^{76}$ the taxpayer cited Wood $v$ United States ${ }^{77}$ in opposition to the government's position that payments under a disability plan may be excluded from "income" for federal tax purposes only where the amount of payment varies in proportion to the type and severity of the employee's injury. Certainly Wood supported the taxpayer: Wood allowed the exclusion, and the benefit plan there did not link the amount of payment to the type or severity of the injury. But in Wood the government did not raise the issue of proportionality. I agree with the en banc court in Beisler that "unstated assumptions on non-litigated issues are not precedential holdings binding future decisions." the same token, such assumptions cannot create a conflict with decisions that address and decide the issue.

Again, fundamental concepts of precedent underlie this conclusion. Lawyers, clients, and district judges cannot reasonably rely on propositions of law nowhere stated or defended in an opinion. More important, if unstated assumptions on non-litigated issues (even if necessary to the decision in a logical sense) were deemed binding, the effect would be to establish the law of the circuit without any panel's ever having considered the merits of the competing arguments.

A more difficult situation arises where the earlier panel did address the issue, but in a footnote or a sentence or two because the issue was not regarded as important. It is tempting to say that perfunctory holdings should be no more binding than unstated assumptions. Why, after all, should a panel's casual treatment of a

${ }^{76} 787$ F2d 1325 (9th Cir 1986), aff'd en banc, 814 F2d 1304 (9th Cir 1987) (Beisler II).

77590 F2d 321 (9th Cir 1979).

${ }^{78}$ Beisler II, 814 F2d at 1308, quoting Sakamoto v Duty Free Shoppers, Ltd., 764 F2d 1285, 1288 (9th Cir 1985). 
point barely argued by the parties preclude reconsideration in a case where the issue is truly central to the dispute? The answer is that the distinction between "perfunctory" and "fully considered" holdings is simply too subjective a basis for deciding whether a given proposition should bind later panels. In contrast to the unstated assumption, the cryptic holding will appear in indexes and annotations, and lawyers can reasonably rely on it as stating the law of the circuit. ${ }^{79}$

Yet even if the distinction between "supporting" and "compelling" authority is accepted, the concept suggested here remains troublesome. On the one hand, to say that case 1 requires a particular result in case 2 is to say that the distinctions between them are irrelevant as a matter of law. But, by hypothesis, the panel in case 2 has found that the distinctions are not only relevant but controlling. How can a prior precedent be "compelling" when it did not in fact compel the same outcome?

The answer is that the precedent need not be compelling in an absolute sense but only in the sense that counsel's reliance on it was reasonable when viewed from the perspective of the law as it stood before the new decision. For purposes of this inquiry I would deem the losing counsel's argument to be reasonable if (a) it was accepted by the district court; ${ }^{80}$ (b) it was accepted by a dissenter in the court of appeals; (c) it was accepted by other circuits; or (d) the panel itself explicitly recognized that the argument was strong (albeit ultimately unpersuasive) ${ }^{81} \mathrm{~A}$ precedent could also be "arguably compelling" if the earlier panel's rationale, taken as a whole, fit the facts of the later case as well. ${ }^{\mathbf{8 2}}$

Whether a particular precedent can reasonably be relied upon as requiring a similar result in a new case will often depend on the holdings and rationales of other relevant precedents. In particular, where one or more intervening decisions have distinguished the earlier ruling and reached results that are "different" in the sense I have described, it would not be reasonable to read the earlier case

79 For an illustration of the problems generated by brief holdings in footnotes, see the discussion of Shuffler $v$ Heritage Bank, 720 F2d 1141, 1145 n 1 (9th Cir 1983), in note 138.

so This element of the definition must be qualified in one respect. A precedent that was arguably (or even clearly) compelling at the time of the district court's ruling may lose that status by reason of intervening decisions.

si See, for example, USCP-Wesco, Inc. v NLRB, 827 F2d 581, 584-85 (9th Cir 1987) (describing at length and distinguishing case involving "a superficially similar situation").

${ }_{82}$ Conversely, a precedent could not be "arguably compelling" if the earlier decision explicitly adverted to facts or considerations not present in the later case. Such references can be negative as well as positive, as where the earlier panel notes that "we do not have here a case where ...." 
as establishing the broad proposition that might be deemed the "rule of the case" if the case stood alone. ${ }^{83}$ For example, in Amato $v$ Bernard, ${ }^{84}$ the court held that "as a matter of sound policy" courts should generally require exhaustion of administrative remedies before exercising jurisdiction over suits under ERISA, the federal pension law. But in a later case, Amaro $v$ Continental Can Co. ${ }^{85}$ the court distinguished Amato and held that exhaustion is not required when the plaintiff claims a violation of rights afforded by the statute, as opposed to rights under a particular pension plan. With Amaro on the books, defendants in pension litigation could no longer rely on Amato as establishing a broad exhaustion rule; at best they could use Amato as a supporting precedent in the course of arguing that their dispute resembles Amato more than it does Amaro. ${ }^{86}$ (There remains the possibility that Amaro itself created a conflict with Amato; that determination would require application of step three of the analysis.)

\section{Step three.}

The analysis thus far suggests that there is at least the appearance of conflict, and consequently a serious potential for uncertainty, whenever a panel has distinguished a relevant circuit precedent that the losing counsel reasonably relied on as requiring a contrary result. But these circumstances do not necessarily mean that the conflict is genuine, or that the coexistence of the two (or more) decisions creates significant uncertainty for lawyers and lower courts. Whether conflict has been avoided and uncertainty minimized will depend on the cogency and clarity of the distinctions drawn by the later panel. In other words, step two looks at the law as it existed before the later panel issued its decision; step three takes the later panel's decision and its rationale into account.

Cogency and clarity are distinct criteria. Cogency turns on whether the distinction drawn by the later opinion is grounded, through reasoned explanation that comports with the norms of legal argumentation, in the policy considerations underlying the rules. Clarity depends on whether the distinction has been articu-

${ }^{83}$ The precedential value of a Ninth Circuit decision may, of course, be changed by Supreme Court rulings as well. See, for example, Glover v Tower, 700 F2d 556 (9th Cir 1983), aff'd, 467 US 914 (1984).

${ }^{84} 618$ F2d 559, 568 (9th Cir 1980).

ss 724 F2d 747 (9th Cir 1984).

${ }^{80}$ See Fujikawa $v$ Gushiken, 823 F2d 1341 (9th Cir 1987) (holding that case more closely resembles Amaro than Amato since claim was based on alleged statutory violation). 
lated in a way that later courts and lawyers can readily apply.

Obviously, there is no yardstick that will measure, objectively and a priori, the cogency and clarity of the distinctions drawn by a panel. In the end, it will be necessary to investigate the way the cases have been treated in the courts and law offices. Still, it is possible to make some provisional judgments, and I do so to illustrate the operation of the criteria. For example, my initial reaction to Amaro, the pension case discussed above, ${ }^{87}$ is that the distinction it draws between suits to enforce rights under a pension plan and suits to enforce rights under the pension statute is one that is relatively easy to apply and not likely to give rise to confusion. But this reading may underestimate the ingenuity of lawyers seeking entree to federal court.

A more debatable distinction is furnished by a pair of cases construing the "opposition" clause of Title VII of the 1964 Civil Rights Act. ${ }^{88}$ Under that clause, it is unlawful for an employer to discriminate against an employee for opposing any employment practice made unlawful by the statute. In the first case, Silver $v$ $K C A$, Inc., ${ }^{89}$ the plaintiff had been discharged for protesting a racial slur directed at a co-worker by Warrington, another worker in the office. The Silver court found no Title VII violation, holding that the opposition clause does not protect employees where "the basis for the discharge is the employee's opposition to a racially discriminatory act of a co-worker rather than [an] unlawful employment practice by the employer." the plaintiff"s argument that "the policy considerations and congressional purposes underlying Title VII require protection of an employee who opposes 'a racially derogatory incident.' "91

Five years later, in EEOC $v$ Crown Zellerbach Corp. ${ }^{92}$ the defendant employer was charged with violating the clause by disciplining employees who had protested the presentation of an affirmative action award to $\mathrm{McColm}$, an employee whom they described as a racist. The employer relied on Silver as establishing that "opposition to McColm's personal biases or racial slurs could not constitute 'opposition to an unlawful employment practice' protected under [Title VII]." "93 This was certainly a reasonable contention,

${ }^{87}$ See text at notes $84-86$.

${ }^{88}$ Civil Rights Act of 1964, 42 USC $\S 2000 \mathrm{e}-3(\mathrm{a})$ (1982).

${ }^{89} 586$ F2d 138 (9th Cir 1978).

so Id at 140 .

21 Id at 141.

${ }^{82} 720$ F2d 1008 (9th Cir 1983).

${ }^{93}$ Id at 1013. 
and I would classify Silver as an "arguably compelling" precedent for the defendant. However, the Crown Zellerbach court ruled for the plaintiffs, distinguishing Silver on the ground that:

McColm, as the personnel manager at the [employer's] warehouse, was largely responsible for the [employer's] employment practices within the warehouse. As such, he occupied a position fundamentally different from Warrington, who was an ordinary employee in a drafting studio. . . . Consequently, the [plaintiffs'] objections to discriminatory practices by McColm were effectively objections to 'unlawful employment practices' by Zellerbach. ${ }^{94}$

Although the question is close, I think that the Crown Zellerbach court distinguished Silver in a way that averted a potential intracircuit conflict. Silver did, after all, involve an "ordinary employee," even though the opinion did not emphasize the point. The Crown Zellerbach court could cogently argue that bigotry on the part of management employees would affect the employer's "employment practices" in a way much different than the bigotry in Silver. The distinction is thus adequately grounded in the policy considerations underlying the rules. As for clarity, one can imagine borderline cases, but on the whole, this distinction is probably one that can be applied relatively easily. ${ }^{95}$

It is more difficult to reconcile a pair of recent decisions involving the application of the primary jurisdiction doctrine to criminal prosecutions. In the first case, United States $v$ Yellow Freight System, Inc. ${ }^{96}$ the court of appeals held that the district court had erred in refusing to grant a stay of criminal proceedings pending a determination by an administrative agency. In the second, United States v General Dynamics Corp., ${ }^{97}$ the court held that the district court erred in granting such a stay. A dissent in the later case relied on Yellow Freight, but the majority distinguished that precedent in a single sentence:

Only where an issue unambiguously requires initial agency determination under the primary jurisdiction doctrine, see, e.g., Yellow Freight Sys., 762 F2d at 462 [sic], and the referring

s4 Id at 1013-14.

${ }^{98}$ A district court in another circuit read the cases somewhat differently, but agreed that "[ $t$ ] he Crown Zellerbach court clearly distinguished the holding in Silver." Blizzard v Newport News Redevelopment \& Housing Auth., 670 F Supp 1337, 1343 n 5 (E D Va 1984).

98 762 F2d 737 (9th Cir 1985).

97828 F2d 1356 (9th Cir 1987). 
court has the authority to review the agency's order, can the agency's regulatory interests be required or allowed to subordinate the government's authority to prosecute criminal offenses. ${ }^{98}$

Neither the opinion in Yellow Freight nor that in General Dynamics gives any clue as to why an agency determination was "unambiguously require[d]" by the "issue" in Yellow Freight but not by the issue in General Dynamics. And the brief discussion in Yellow Freight said nothing at all about the referring court's authority to review the agency order. Thus, in future cases involving other issues or agencies, it will be impossible to determine whether General Dynamics or Yellow Freight is controlling. ${ }^{99}$

In this instance, the fact that the rule articulated by the General Dynamics court had not been stated anywhere in Yellow Freight contributes to the confusion. As a general matter, however, the third step of my analysis does not depend on whether the distinction drawn by the later panel can be found in the earlier opinion. What the later panel is obliged to respect is the result, not the stated rationale, of a precedent. Of course, the later panel cannot simply say that the earlier case was "different" or insist, without elaboration, that the facts are "distinguishable." Nor is it enough to offer a new verbal formulation without showing-as the General Dynamics panel did not-how the new rule requires (or at least permits) different results in the two cases. But if the later panel, making legitimate use of the "leeways" of precedent, ${ }^{100}$ reformulates the rule of the earlier case in a way that preserves the earlier result while allowing for a contrary result on the new facts, it has

${ }^{88}$ Id at 1366-67. The import of this distinction is clouded by the fact that the page cited by the General Dynamics court is not found within the Yellow Freight opinion.

"2 When I first began work on this article, I expected to cite United States v Aguon, 813 F2d 1413 (9th Cir 1987), as a prime example of a panel's failure to draw a clear distinction between the case before it and an arguably compelling contrary precedent. The majority acknowledged the prior holding in United States $v$ McClelland, 731 F2d 1423 (9th Cir 1984), that "[a]n official may be convicted [under the Hobbs Act] even though he did not make a threat or an inducement." Aguon, 813 F2d at 1418. But the panel went on to rule that "the jury [must] find that the public official did something, under color of his office, to cause the giving of benefits." Id, quoting United States $v$ O'Grady, 742 F2d 682, 688 (2d Cir 1984) (emphasis added). The distinction between "inducing" payments and "[doing] something . . . to cause" payments is subtle, to say the least, and almost certainly the coexistence of the two cases would have caused confusion among prosecutors, defense lawyers, and district courts. Consistent with that view, the full court voted to grant en banc rehearing. Although the en banc court reached the same result as the three-judge panel, it forthrightly overruled McClelland, thus acknowledging that the panel decisions were in conflict. United States v Aguon, 851 F2d 1158 (9th Cir 1988).

100 Llewellyn, The Common Law Tradition at 220 (cited in note 34). 
not done violence to the doctrine of stare decisis. ${ }^{101}$ Nor has it created a conflict. To put it another way, an unnecessarily broad statement of the "rule" of a case can properly be treated as dictum.

When a preliminary version of this article was presented to the Ninth Circuit Judicial Conference, commentators argued that this approach is too narrow. In their view, a later panel is obliged to respect not only the "rule" of an earlier case, but also the purpose of the rule, i.e., what the earlier panel was attempting to accomplish. Some judges have gone even further, stating that the binding effect of a decision extends to anything that the earlier panel intended to be part of its resolution of an issue in the case. "Dicta" would be limited to statements that the earlier panel explicitly labelled as beyond the scope of its decision.

The narrower view, however, is firmly grounded in the theory of precedent as a device that at once recognizes and limits the authority of courts to make law as a corollary of their power to decide cases. Under that theory, the judges of one panel cannot, by casting their rule in unnecessarily broad terms, preempt later panels from reconsidering (or, more accurately, considering) aspects of the same legal problem that were not present in the earlier case. The contrary view would freeze the development of legal rules in a way that is quite inconsistent with the tradition of the common law. It would be especially pernicious in the federal courts, where gradual adjustment and modification of existing law enable a life-tenured judiciary to reflect, over time, changes in the will of the people as manifested in the election of a new President.

This is not to say that the earlier panel's rationale is irrelevant. As a practical matter, the later distinction is more likely to prove clear and cogent if it was at least hinted at in the earlier case. For example, in United States $v$ Piner, ${ }^{102}$ the Ninth Circuit's first decision on the constitutionality of Coast Guard searches in territorial waters, the panel held that "the random stop and boarding of a vessel after dark for safety and registration inspection without cause to suspect noncompliance" violated the Fourth Amendment. ${ }^{103}$ However, language in the opinion indicated that

101 The leeways of precedent are wide, but they have limits. If a panel, rather than narrowing the scope of a rule, attributes to the earlier decision an entirely different rationale, it has gone too far. See Gutierrez v Municipal Court, 861 F2d 1187, 1191 (9th Cir 1988) (Kozinski dissenting from denial of rehearing en banc), vacated 109 S Ct 1736 (1989).

${ }_{102} 608$ F2d 358 (9th Cir 1979).

${ }^{103}$ Id at 361. 
"administrative standards so drafted that the decision to search is not left to the sole discretion of the Coast Guard officer" might justify a stop and boarding even in the absence of individualized cause. ${ }^{104}$ Three years later, in United States $v$ Watson, ${ }^{105}$ that dictum became law. The court found no Fourth Amendment violation in a document and safety inspection on the high seas after dark without even a founded suspicion of noncompliance, because " $[t]$ he stop did not involve an exercise of discretion by an officer in the field, but instead was conducted pursuant to an administrative plan."108 Watson thus created no conflict-a conclusion strengthened by the fact that some months later the same distinction was invoked by the author of the Piner opinion in upholding another Coast Guard search.107

On the other hand, the reason no mention occurs of the distinction drawn by the later case may be that neither the parties nor the court considered the effect of a factual variation that by hypothesis was not present and could not have affected the result. If the later panel blindly applies the broader rule when the factual variation does arise, the law of the circuit will be established without focused adversary argument and without focused judicial consideration. And the earlier panel will be ceded a lawmaking power that in a democratic society it should not have.

The point is further illustrated by the two cases interpreting the "opposition" clause of Title VII. It is very difficult to read Silver, the earlier case, as drawing a distinction between an "ordinary employee" and an employee "largely responsible for [the employer's] employment practices."108 Rather, the Silver opinion draws the line between acts of "the employer" and acts of "employees" or "co-workers", and seems to lump all employees together. ${ }^{109}$ Thus, if Silver were read for its maximum value as precedent, it would establish the proposition for which the employer in Crown Zellerbach cited it. Under traditional theory, however, the Crown Zellerbach court was not obliged to read Silver for its maximum value. And by reading Silver narrowly, the later panel was able to formulate a rule that drew upon the experience of five additional years of litigation under Title VII (and perhaps a different

\footnotetext{
30r Id.

${ }^{103} 678$ F2d 765 (9th Cir 1982).

${ }^{108}$ Id at 773.

${ }^{107}$ United States v Eagon, 707 F2d 362, 365 (9th Cir 1982).

${ }_{108}$ Crown Zellerbach, 720 F2d at 1013-14.

309 Silver, 586 F2d at 141-42.
} 
societal perception of racial slurs in the workplace), without disturbing the rule of the earlier case as applied to acts that pose less of a threat to the congressional judgments underlying the statute. ${ }^{110}$

In taking this position, I express no view about the wisdom or soundness of the Crown Zellerbach rule. The issue at the third stage is not whether the distinctions should have been drawn but whether they can be understood and applied by those who will look to the law of the circuit to determine their rights and obligations. If the answer is affirmative, it matters not that strong-perhaps, in the view of a particular observer, stronger-arguments could be made that the two cases should have been treated alike.

\section{The Omitted Precedent}

In the paradigm case, the later panel has made some effort, however brief or cryptic, to distinguish an arguably compelling contrary precedent, and the question is whether the distinction can be understood and applied by other judges and lawyers. Suppose, however, that the later panel fails to mention, let alone distinguish, an apparently inconsistent ruling by an earlier panel. Where this occurs, it is obviously impossible to complete the third step of the analysis. And if losing counsel has failed to cite the case, it is impossible to undertake the analysis at all. How, then, would the suggested approach deal with the situation where, at a later time, a judge or lawyer asserts that the two precedents are in conflict?

No answer is completely satisfactory, but the best approach is to proceed with the analysis as though counsel in the second case had at least mentioned the earlier decision. If the earlier ruling proves to be an arguably compelling contrary precedent, the later panel has by definition created an intracircuit conflict because without an articulated distinction lawyers and other courts will have no way of knowing which situations fall on one side of the line rather than the other. If the earlier decision is merely supporting for the losing side, there is no conflict-though there may still be some confusion because lawyers and lower court judges who make use of the cases will be required (at least initially) to work independently and unaided to reach that conclusion.

The problem is illustrated by a series of cases involving the question whether to apply disparate impact analysis to a Title VII

${ }^{110}$ For another illustration of this pattern, see the treatment of Alcaraz $v$ Block, 746 F2d 593 (9th Cir 1984), in Linoz v Heckler, 800 F2d 871, 877 n 10 (9th Cir 1986). 
suit challenging an employer's use of subjective criteria for hiring or promotion. In Heagney $v$ University of Washington, ${ }^{111}$ the first Ninth Circuit panel to consider the issue rejected the use of impact analysis. However, a later panel, without citing the earlier decision, held in Wang $v$ Hoffman ${ }^{112}$ that impact analysis was appropriate. Obviously, Heagney was a "relevant precedent" that reached a result contrary to that of Wang. Indeed, it was an arguably compelling contrary precedent. Wang thus created an intracircuit conflict. ${ }^{113}$

How would a situation like this arise? There can be at least three possible explanations. First, what one judge has called "conspicuous disparities in the quality of advocacy"114 may lead the panel away from existing relevant precedents. The parties may fail to mention the precedent altogether, or one party may persuasively (but incorrectly) distinguish the precedent, and his adversary-through lack of ability, lack of time, or pure carelessness-may fail to rebut the distinction effectively. The judges in turn may miss the case (or the flaw in the argument) because of caseload pressures.

Second, a panel may fail to mention recently decided precedents that were not published until after the opinion had been drafted. It is all too easy to assume that the filing date of an opinion marks, within a week or two, the date on which the opinion was completed. Sometimes that will be the fact, but more often the opinion will have been written in near-final form weeks or even months earlier, with the interval devoted to the exchange of memoranda among the judges on the panel. Moreover, even if a relevant case was in print when the later opinion was being drafted, it may not have found its way into the indexes and digests. The Ninth Circuit has implemented procedures designed to avoid conflicts during this period of vulnerability, ${ }^{116}$ but the procedures are not infallible.

Finally, there is the possibility that the judges on the later panel knew about the earlier decision but concluded-however unpersuasively to others-that it had so little relevance that it was not even worth citing. Cynics might assume that the judges

111642 F2d 1157 (9th Cir 1981), over'd, Atonio v Wards Cove Packing Co., 810 F2d 1477 (9th Cir 1987) (en banc).

${ }^{112} 694$ F2d 1146 (9th Cir 1982).

11 The conflict was resolved through rehearing en banc. Atonio, 810 F2d 1477 .

214 Author's interviews.

11 See text at notes $20-22$. 
reached that conclusion because they wanted so badly to believe that it was so. No doubt this will sometimes be the explanation; with judges as with others, the wish can be the father to the thought. ${ }^{116}$ But it is also true that in a common law system there can be good faith disagreements not only about the scope of a precedent but also about the nature of the issue. Fortunately, the available evidence indicates that the phenomenon is not a common one. ${ }^{117}$

\section{Multiple Relevant Precedents Reaching Different Results}

The discussion thus far has posited a situation in which no more than one or two circuit precedents are "relevant" to the question raised by a new appeal, and the question has been whether the panel's decision has created, or is likely to create, an intracircuit conflict. But much of the concern about inconsistency in the law of the Ninth Circuit has focused on a different phenomenon: a multiplicity of decisions already on the books addressing the same legal problem, with some coming out on one side, some on the other. For example, from 1982 through mid-1987, the Ninth Circuit issued eleven published opinions addressing the question whether a union violated its duty of fair representation in processing employee grievances. Five decisions ruled in the employee's favor; the other six rejected the claim. From 1981 through 1986 the court issued more than twenty-five published opinions construing the "extreme hardship" provisions of the immigration laws. The year 1983 alone brought seven such decisions, divided four-three in outcomes. ${ }^{118}$ In the three and a half years that followed the Supreme Court's unanimous ruling in Allis-Chalmers Corp. $v$ Lueck, ${ }^{119}$ the Ninth Circuit issued sixteen published decisions on the preemptive effect of $\S$ 301 of the National Labor Relations Act. ${ }^{120}$ Most found the state law claims preempted, but several important precedents did not. ${ }^{121}$

${ }^{126}$ See Greenhow v Secretary of HHS, 863 F2d 633, 636 (9th Cir 1988).

117 See section III.B.

118. See discussion in text accompanying notes 215-18.

11947 US 202 (1985).

${ }^{120}$ In Lueck, the Supreme Court commented that "[t]he full scope of the preemptive effect of federal labor-contract law remains to be fleshed out on a case-by-case basis." 471 US at 220. That proved to be an understatement.

${ }^{121}$ Compare, for example, Utility Workers of America $v$ Southern Calif. Edison, 852 F2d 1083 (9th Cir 1988), cert denied 109 S Ct 1530 (1989) (state law challenges to employer's drug testing program preempted, even if based on rights under California constitution), with Ackerman v Western Electric Co., 860 F2d 1514 (9th Cir 1988) (claim under California handicap discrimination law not preempted). 
A 1988 opinion adjudicating a challenge to in personam jurisdiction cited fourteen Ninth Circuit precedents, most of them upholding jurisdiction but others finding it wanting. ${ }^{122}$

These issues have a number of characteristics in common. The litigated disputes are numerous. The legal rules are fact-specific. The governing law does not point strongly in one direction or another; often, the law is in a state of evolution. Second-level rules may provide some degree of predictability, but they do not fully constrain the discretion vested in the panels by the primary rules. Finally, many of the issues (though by no means all) implicate deeply felt choices between competing societal values.

Almost invariably, the combination of these circumstances will result in the phenomenon I have described: a large number of decisions on point, some supporting the claim in question, others rejecting it. When that pattern occurs, it will be almost impossible for any new panel to distinguish all of the contrary precedents in a way that is both clear and cogent. Thus, under the three-step analysis, I would conclude that a conflict exists. Indeed, intuition alone tells us that under the circumstances posited, a certain degree of disarray is inevitable, at least when the decisions are not made by the same groups of individuals.

One caveat is in order, however. Lawyers often talk about "extreme hardship," "substantial similarity," "disparate treatment," and the like as though the phrases encompass unitary issues. Thus, if an alien seeks suspension of deportation on the ground of extreme hardship, counsel will probably regard all extreme hardship cases as "relevant" in the sense used here. Yet it is quite possible that if one looked at the decisions carefully, it would be possible to identify discrete subcategories of cases in which there were no contrary results, or in any event no arguably compelling contrary precedents. Nevertheless, at this stage I shall make no attempt to pursue that line of inquiry. Instead, I shall assume that multiple relevant precedents reaching different results do constitute intracircuit conflicts, and will leave to section III the task of determining the consequences of that precedential array.

\section{E. Conclusion}

I have identified three kinds of situations in which there is a strong likelihood that rulings by different panels will give rise to disarray or confusion in the law of the circuit. A panel may have

${ }^{122}$ Sinatra v National Enquirer, Inc., 854 F2d 1191 (9th Cir 1988). 
distinguished an arguably compelling contrary precedent in a way that is either unclear or apparently without foundation in the policies underlying the rules. Or, a panel may have failed to mention an arguably compelling contrary precedent. Finally, multiple precedents may be relevant to the particular issue, some pointing in one direction, some in the other.

To apply this theory to the jurisprudence of the Ninth Circuit Court of Appeals, we must first determine the extent to which these three patterns have characterized the court's panel decisions during the last decade. We can then ask whether the decisions have in fact resulted in confusion or uncertainty. Those inquiries are pursued in the next section of this article.

\section{Measuring the Incidence of Intracircuit Conflict}

To fully assess the relationship between the size of an appellate court and the extent of inconsistency in the law, it would be necessary to make comparisons between the Ninth Circuit and one or more smaller circuits. At one point I contemplated a research project along those lines, but ultimately I concluded that the effort required would be enormous, while the number of relevant variables is so great that it would be impossible to reach any meaningful conclusions. Instead, I concentrated on estimating the extent of inconsistency within the Ninth Circuit-itself a task of no small difficulty. If, as the research thus far leads me to believe, there is not a great deal of inconsistency, it will be unnecessary to make comparisons.

\section{A. Method}

I began by selecting two random samples of published opinions handed down by the Ninth Circuit Court of Appeals, one from 1983, the other from 1986. The sample for each period consisted of all Ninth Circuit panel decisions in every fifth volume of the Federal Reporter from that year. Because of the fortuities of West's publication schedules, I ended up examining 22 percent of the court's precedential output for 1983 and 23 percent for 1986. Each decision was analyzed in accordance with the three-step formulation. For cases not eliminated at the first stage (i.e., because there were one or more relevant circuit' precedents that reached a contrary result), I also identified the precedent that most strongly supported the party whose position was rejected by the court of appeals.

In determining whether a precedent was "supporting" or "ar- 
guably compelling" for the losing party, I relied on the opinion in the later case as the source of the facts on which to base the comparison. Admittedly, this approach may have entailed some distortion: the judges ordinarily reach at least a tentative decision at the conference following oral argument, and the account of the case in the opinion would be written from that perspective. As a result, facts may be highlighted or obscured so as to make the contrary precedents look more dissimilar than they would in a "neutral" account. Perhaps it would have been preferable to use only the published opinion in the earlier case and the record and briefs on appeal in the later one. Limitations of time and resources precluded that approach. Nevertheless, I do not think the actual distortion was great; for the most part, the factual differences between the cases were straightforward, leaving little room for manipulation, conscious or otherwise. ${ }^{123}$

For each case that was not excluded at the first step, I attempted to trace the subsequent history of the common legal issue to determine if the coexistence of arguably inconsistent decisions had created confusion or uncertainty. In other words, I did not assume the correctness of my distinction between "supporting" and "compelling" precedents; rather, I sought to determine if that distinction would hold up in practice.

Indicia of confusion were apparent inconsistencies in the later decisions, disagreement within panels, disagreement between appellate panels and district courts, and frequent litigation. If one or more of these indicia were present, I examined the cases further to determine the extent to which the confusion was produced by the coexistence of the apparently conflicting decisions rather than by other factors.

I was particularly interested in searching for conflicts created by a panel's outright failure to mention relevant precedents that reached contrary results. I assumed that if silent conflicts existed, they would become manifest in later decisions when judges and law

${ }^{123}$ For example, in United States $v$ Jenkins, 785 F2d 1387 (9th Cir 1986), the defendant in a criminal prosecution argued that the trial court had erred in denying his motion to be tried separately so that he could call a codefendant as a witness. The defendant relied on United States v Seifert, 648 F2d 557 (9th Cir 1980), in which the court of appeals found abuse of discretion in the denial of a severance motion. But in the earlier case the trial court had ruled that there was a high probability that the codefendant would have testified favorably to Seifert in a separate trial. In Jenkins there was no such finding, and indeed the defendant had asserted in his original severance motion that his codefendant's grand jury testimony actually inculpated him. These are irrefragable facts, and it is hard to see what could be added to or subtracted from them to cast doubt on the conclusion that Seifert was only a supporting precedent for the defendant in Jenkins. 
clerks, using a full array of research tools, discovered the arguable discrepancy. ${ }^{124}$

Many of the cases in the sample contained multiple holdings and thus the potential for creating multiple conflicts. Student assistants examined the precedents cited in the opinions and opened a separate record for any discrete issue on which there were one or more contrary Ninth Circuit rulings. ${ }^{125}$ I also created separate records for other issues that appeared likely, for one reason or another, to be the subject of frequent litigation. The 1983 sample yielded 250 separate records; the 1986 sample, more than 300 . The number was higher for 1986 because I tended to be more zealous in creating separate records for issues on which there were no contrary precedents.

In this article, I shall present quantitative data only on the 1983 sample; however, illustrations of the various patterns will be drawn from both samples. Results from the 1986 sample have not yet been thoroughly analyzed and will be published in a later article. Preliminary review of the cases in the 1986 sample gives no reason to believe that the patterns were substantially different.

\section{B. The 1983 sample}

1. Step one cases and the omitted precedents.

The 1983 sample contained a total of 175 panel decisions. Four of these were brief orders of remand in cases that had received plenary consideration in the Supreme Court. In sixty-eight, or 40 percent, of the remaining cases the court cited no contrary precedents on any issue. Thus, under the three-step approach, there was no possibility of conflict-unless the court failed to cite an earlier ruling that was not only contrary but arguably compelling for the losing side.

Research into later case law revealed seven instances of what I shall call omitted precedents-contrary decisions that should have been cited (because they were "relevant" in the broad sense described earlier) but were not. ${ }^{128}$ Omitted precedents also existed

124 As part of this inquiry, I Shepardized all cases in the sample. Most of the research was conducted in the summer of 1988 , with some supplemental Shepardizing to bring the work up to date through the end of 1988.

${ }^{125}$ Issues were defined functionally, by reference to lines of authority. Thus, if a litigant made two related arguments invoking two separate lines of precedent, the issues were recorded separately.

126 "Omitted precedents" do not include contrary decisions that were cited by a dissenting or concurring opinion but not discussed by the majority. The phenomenon did not 
for three sample cases that did cite contrary decisions, but on other issues. In nine of the ten cases, however, the omitted precedents were at best supporting for the losing party. The panels did not create conflicts by failing to cite the contrary rulings; at worst the new decisions introduced some unnecessary uncertainty into the law.

A good example is United States $v$ Woods, ${ }^{127}$ a criminal case in which the question was whether the police had probable cause for an arrest based in part on an informant's tip. The court listed the facts known to the officers at the time of the arrest and held that these met the constitutional standard. Quoting at length from Draper $v$ United States, ${ }^{128}$ a 1959 Supreme Court decision, the court noted that "[t]he information given by [the informant] was more detailed and accurate than that found sufficient to show probable cause in Draper."129 The opinion made no mention of United States $v$ Freitas, ${ }^{130}$ decided seven months earlier, in which another panel found probable cause to be lacking. ${ }^{131}$ The Freitas panel also invoked Draper, but concluded that "the [informant's] report involved here was not nearly as specifically detailed as that in Draper; nor were the details corroborated as thoroughly as those in Draper."132 With both cases using Draper as a benchmark, it could hardly be doubted that Freitas was a relevant precedent in Woods; by the same token, the later panel could have contributed to better understanding of a confused area of the law by explicitly comparing the information known to the officers at the time of the two arrests. ${ }^{133}$ But because the existence of probable cause turns on the facts of the particular case, the failure to cite Freitas did not create a conflict. ${ }^{134}$ The same can be said, even more strongly,

occur often, and in the one case where a contrary ruling cited by the dissent was arguably compelling, the majority opinion implicitly distinguished it. See Miranda $v$ Southern Pacific Transp. Co., 710 F2d 516 (9th Cir 1983) (discussed at notes 165-71).

127720 F2d 1022 (9th Cir 1983).

128358 US 307 (1959).

120 Woods, $720 \mathrm{~F} 2 \mathrm{~d}$ at 1029.

130716 F2d 1216 (9th Cir 1983).

131 The Freitas opinion was initially issued before oral argument in Woods, but publication in the Federal Reporter appears to have been held up pending the disposition of a petition for rehearing. However, the amended opinion was issued on Sept. 26, 1983, six weeks before the Woods opinion came down.

132 Freitas, $716 \mathrm{~F} 2 \mathrm{~d}$ at 1223.

153 The task of reconciling the cases was left to a later panel. See United States $v$ Fixen, 780 F2d 1434, 1437-38 (9th Cir 1986).

${ }^{134}$ Given that the ultimate question is whether inconsistency becomes more of a problem as the number of judges on the court increases, it is relevant to note that the same judge can view "probable cause" differently depending on the particular facts. Compare 
of cases where not only is the legal rule fact-specific, but its application in the district court is reviewed on an abuse-of-discretion standard. ${ }^{135}$

Two of the omitted precedents involved variations on a single troublesome (though seldom dispositive) issue: the degree of deference to be accorded a trial judge's interpretation of the law of the state in which the district is located. ${ }^{136}$ In 1984 , an en banc panel provided a definitive resolution of the question after acknowledging that two recent decisions had "indicate[d] some departure from" the standard generally applied in the circuit. ${ }^{137}$ In three other sample cases, the omitted precedents had obvious distinguishing features; nevertheless, a sentence or two articulating the difference would have clarified the relationship for later researchers. ${ }^{198}$

United States v Fixen, 780 F2d 1434 (9th Cir 1986) (finding of probable cause upheld) (Nelson, J), with United States $v$ Delgadillo-Velasquez, 856 F2d 1292 (9th Cir 1988) (finding of probable cause reversed) (Nelson).

${ }^{135}$ This description fits three of the omitted precedents in the 1983 segment of the study. In two of the cases, criminal defendants challenged the trial court's denial of a motion for severance. Both decisions rejected the claim, finding no prejudice. See United States v Ramirez, 710 F2d 535, 545-47 (9th Cir 1983); United States v. Cowley, 720 F2d 1037, 1041 (9th Cir 1983). Neither opinion mentioned United States $v$ Donaway, 447 F2d 940, 943 (9th Cir 1971), in which the court held that failure to sever did prejudice the defendant. Donaway was distinguished in another severance case in the sample, United States v. Gee, 695 F2d 1165, 1169 (9th Cir 1983). The third case was United States v Bowman, 720 F2d 1103, 1105 (9th Cir 1983) (finding no abuse of discretion in admission of evidence of prior assault conviction; not citing United States v Bettencourt, 614 F2d 214 (9th Cir 1980) (finding abuse of discretion in admission of evidence of prior assault, but holding error harmless)).

${ }^{138}$ The sample cases were Philpott $v$ A.H. Robins Co., 710 F2d 1422, 1423 (9th Cir 1983); and Lassen Canyon Nursery v Royal Ins. Co., 720 F2d 1016, 1017 (9th Cir 1983). Both followed the deferential standard generally applied by the Ninth Circuit at that time; neither cited the decisions that appeared to mark a departure from that approach.

${ }^{137}$ Matter of McLinn, 739 F2d 1395, 1397 n 1 (9th Cir 1984) (en banc).

138 In Bestran Corp. $v$ Eagle Comtronics, Inc., 720 F2d 1019 (9th Cir 1983), the court held that a motion for reconsideration under a local rule was a motion to alter or amend the judgment under FRCP 59(e) that nullified the notice of appeal. No mention was made of Miller v Transamerican Press, Inc., 709 F2d 524, 527-28 (9th Cir 1983) (motion styled as one to amend judgment is properly characterized as Rule 60(a) motion to correct error or omission, and does not nullify notice of appeal). In Barnes $v$ Donovan, 720 F2d 1111 (9th Cir 1983), the court deferred to the Secretary's interpretation of a provision of the Redwood Park Expansion Act because the employees' alternative interpretation was unreasonable. The opinion did not cite Local 3-98, Int'l Woodworkers of America v Donovan, 713 F2d 436 (9th Cir 1983) (rejecting Secretary's interpretation of different provision of Act).

Of particular interest is Shuffler $v$ Heritage Bank, 720 F2d 1141 (9th Cir 1983), in which the court held that the district court's order quantifying sanctions and issuing a writ of execution was void under the general rule that the timely filing of a notice of appeal transfers the action to the court of appeals. Id at $1145 \mathrm{n} 1$. No mention was made of Hoffman v Beer Drivers \& Salesmen's Local Union No. 888, 536 F2d 1268 (9th Cir 1976), a 
The one sample case in which a panel failed to cite an arguably compelling contrary precedent was United States $v$ Gonzalez. ${ }^{139}$ There the panel held that the defendant could be convicted on separate counts for possession of heroin with intent to distribute and for distribution of heroin, even though the two counts grew out of the same transaction. The court relied on United States v Mehrmanesh, ${ }^{140}$ a 1982 case that had rejected a transactional approach in a similar context. Neither Gonzalez nor Mehrmanesh cited United States v Oropeza, ${ }^{141}$ a 1977 decision in which the court held that the two offenses merged when "the sole evidence of possession is found in the distribution transaction."142 However, when the appeal of Gonzalez's codefendant Palafox was argued before another panel, the apparent inconsistency came to light, and after a lengthy exchange of memoranda the court granted en banc review. The en banc panel reaffirmed Oropeza and overruled Mehrmanesh "[i]nsofar as [it] held that one involved in an ultimate distribution is always separately punishable for a preceding sample distribution."143

On the basis of the 1983 sample, it appears that omitted precedents have not constituted a significant source of intracircuit conflict in the Ninth Circuit. ${ }^{144}$ Panels occasionally failed to mention contrary decisions that would (at best) have supported a different result, but when they did, later panels generally corrected the oversight. For the most part, the omitted precedents were very recent decisions that probably had not found their way into digests and citators. ${ }^{145}$ In the one instance where a panel ignored an argua-

labor injunction case in which the court recognized an exception to the general rule for situations where the trial court was "supervis[ing] a continuing course of conduct." Id at 1276. Shuffler could not reasonably have been characterized as involving ongoing supervision to enforce a court order, so Hoffman was not an arguably controlling precedent, but not until two years later did another panel delineate the scope of the exception. Donovan $v$ Mazzola, 761 F2d 1411, 1414-15 (9th Cir 1985).

139715 F2d 1411 (9th Cir 1983).

${ }^{160} 682$ F2d 1303 (9th Cir 1982).

${ }^{141} 564$ F2d 316 (9th Cir 1977).

${ }^{142}$ Id at 323.

${ }^{143}$ United States v Palafox, 764 F2d 558, 562-63 (9th Cir 1985) (en banc).

144 I am aware of at least one case in the 1986 sample in which the panel failed to consider a relevant contrary precedent. In United States v Terrovona, 785 F2d 767, 769-71 (9th Cir 1986) (decided without oral argument), the court relied on dictum in United States $v$ Williams, 651 F2d 644, 647 n 2 (9th Cir 1981), but failed to note that the dictum had been rejected in United States $v$ Thornton, 710 F2d 513, 516 (9th Cir 1983), a case in the 1983 sample that squarely presented the issue.

${ }^{345}$ This suggests that the court could ameliorate the problem by directing the central legal staff to re-classify cases upon the filing of the opinion to reflect the issues actually decided. See Hellman, Maintaining Consistency in the Law of the Large Circuit, in 
bly controlling contrary precedent, the omission was quickly discovered and the court took steps to eliminate the confusion.

\section{Step two cases.}

Simple arithmetic tells us that cases that did not cite at least one contrary precedent were outnumbered by those that did. In the overwhelming majority of these, however, the earlier decisions were at best supportive of the losing party. Generally it took me no more than fifteen or twenty minutes to conclude that there were obvious distinctions between the contrary precedents and the sample case, and that no reasonable lawyer would have argued otherwise.

The study points to a number of recurring situations of this kind. The easiest cases are those in which the statement of the holding or rationale in the earlier opinion explicitly excludes the factual variation presented by the later dispute. For example, in Quantum Exploration v Clark, ${ }^{146}$ the plaintiff relied on YavapaiPrescott Indian Tribe $v W$ tt $^{147}$ to support its claim that the defendant Indian tribe could not rescind a mineral development agreement without the approval of the Secretary of the Interior. Yavapai-Prescott did hold that the tribe in that case could not cancel a lease without the Secretary's approval, and to that extent the decision supported the plaintiff in Quantum Exploration. But the court in Yavapai-Prescott had phrased the question as "whether an Indian Tribe has the authority to terminate a lease executed in accordance with" a law requiring secretarial approval before leasing. ${ }^{148}$ In Quantum Exploration, however, the lease had not yet been approved or disapproved by the Secretary. ${ }^{148}$ The case thus lacked a factual predicate that the earlier decision had assumed and relied on. As a result, the earlier decision could not be a compelling precedent for the plaintiff. ${ }^{150}$

Even if the earlier decision does not explicitly advert to a factual predicate absent in the later case, the importance of the fact may be so evident that no reasonable lawyer could dispute its rele-

\footnotetext{
Hellman, ed, Justice Restructured (cited in note 23) (elaborating upon this recommendation).

148780 F2d 1457 (9th Cir 1986).

147707 F2d 1072 (9th Cir 1983).

148 Id at 1073 (emphasis added).

$360780 \mathrm{~F} 2 \mathrm{~d}$ at 1458.

${ }^{180}$ This pattern can also be seen in the treatment of United States $v$ Beck, 598 F2d 497 (9th Cir 1979), by United States v Jacobs, 715 F2d 1343 (9th Cir 1983).
} 
vance. For example, in Manocchio $v$ Commissioner, ${ }^{151}$ the taxpayer argued that retroactive application of a Revenue Ruling was an abuse of discretion because of the degree of detrimental reliance involved. He cited Schuster $v$ Commissioner, ${ }^{152}$ a case that held the Government estopped from asserting liability upon finding a "profound and unconscionable injury in reliance on the Commissioner's action." But in Schuster the estoppel doctrine was applied on behalf of a third party bank that had acted only as trustee. Schuster supported the estoppel claim in Manocchio, but it could not be a compelling precedent because no reasonable lawyer could have argued that the bank's status as an innocent third party was irrelevant as a matter of law.

Sometimes the distinguishing feature will emerge only in the later case. Thus, in Washington v Penwell, ${ }^{163}$ the district court had granted the state's motion under Federal Rule of Civil Procedure 60 (b) to modify a consent decree in a suit involving prisoners' rights. On appeal, the prisoners' lawyers contended that the district court erred in applying an exclusively contractual analysis to a consent decree. ${ }^{154}$ They relied on Twentieth Century-Fox Film Corp. $v$ Dunnahoo, ${ }^{188}$ which had indeed rejected the argument that a consent decree should be treated as a contract. But in Washington $v$ Penwell the state invoked the Eleventh Amendment as a basis for modifying the decree. Taking into account the extraordinary respect accorded state sovereign immunity by the Supreme Court, ${ }^{156}$ no one could reasonably argue that Dunnahoo was more than a supporting precedent for the prisoners.

In some of the cases, a difference in procedural posture, often reinforced by factual variations, eliminated the possibility that the earlier case could be arguably controlling for the losing side. For example, in McKinley $v$ City of Eloy, ${ }^{157}$ the court upheld a jury finding that "the plaintiff"s first amendment activities were a substantial or motivating factor in his discharge" from his position in public employment. An earlier case had ruled for the defendant on a similar claim, but there the district court had made a factual finding, fully supported by the record, that "first amendment con-

\footnotetext{
161710 F2d 1400, 1403 (9th Cir 1983).

132312 F2d 311, 317 (9th Cir 1962).

153700 F2d 570 (9th Cir 1983).

184 Id at 573.

1ss 637 F2d 1338, 1340 (9th Cir 1981).

168 See, for example, Quern v Jordan, 440 US 332, 338-45 (1979) (rejecting argument that 42 USC $\$ 1983$ abrogates Eleventh Amendment immunity of states).

${ }^{187} 705$ F2d 1110 (9th Cir 1983).
} 
siderations did not motivate the decision not to rehire the [plaintiff]." "158 Given the deference accorded findings of fact by juries and trial judges, the defendants in McKinley could not reasonably have argued that the earlier case compelled a ruling in their favor.

A contrary precedent that might once have been arguably compelling may lose its force through being repeatedly distinguished and never followed. For example, in United States $v$ Samango, ${ }^{189}$ a 1979 decision, the court affirmed the dismissal of an indictment on the ground of prosecutorial misconduct before the grand jury. This precedent was invoked by the defendants in United States v Al Mudarris, ${ }^{160}$ a case in the 1983 sample. Although the court of appeals rejected the prosecutorial misconduct defense, the opinion conceded that "[p]rosecutorial behavior in this case resemble[d] that in Samango" and that the "cumulative effect of [prosecutorial] errors and indiscretions' . . came uncomfortably close to crossing [the] line" requiring dismissal of the indictment. ${ }^{181}$ In light of that concession, I classified Samango as an arguably compelling precedent for the defendants in Al Mudarris. ${ }^{162}$ Three years later, however, when defendants in two of the 1986 sample cases $^{\mathbf{1 6 3}}$ challenged district court refusals to dismiss indictments, the precedential status of Samango had changed. In the interim, defendants had repeatedly invoked the case, but never with success. Thus, both 1986 decisions could legitimately rely on Al Mudarris and ignore Samango. ${ }^{164}$

${ }^{168}$ Nicholson $v$ Board of Educ. Torrance Unif. Sch. Dist., 682 F2d 858, 864 (9th Cir 1982) (emphasis added).

${ }^{180} 607$ F2d 877 (9th Cir 1979).

180695 F2d 1182 (9th Cir 1983).

161 Id at 1188, quoting Samango, 607 F2d at 882, 884 (citations omitted).

${ }_{162}$ This classification may reflect unnecessary caution, since in Samango the court of appeals was reviewing the district court's dismissal of an indictment, while in Al Mudarris the issue was presented on appeal from a criminal conviction after the district court had denied a motion to dismiss. The difference in procedural posture, and the deference accorded trial court rulings in such matters, may have made Samango only a supporting precedent for the defendants in the later case.

${ }^{163}$ United States $v$ Gonzalez, 800 F2d 895, 899 (9th Cir 1986); United States $v$ Venegas, 800 F2d 868, 871 (9th Cir 1986).

${ }^{164}$ One precedent that I thought had been safely buried was resurrected late in 1988, only to be reinterred a few months later. In United States $v$ Steele, 461 F2d 1148 (9th Cir 1972), the court upheld a claim of selective prosecution. Thereafter, the Ninth Circuit never reversed a conviction on the authority of Steele, and two cases in the 1983 sample continued the pattern by finding Steele inapplicable. See United States $v$ Christopher, 700 F2d 1253, 1258 (9th Cir 1983); United States $v$ Wayte, 710 F2d 1385, 1387-88 (9th Cir 1983), aff'd, 470 US 598 (1985). When one of the decisions was affirmed by the United States Supreme Court, I was ready to declare that Steele had been deprived of any precedential vitality it might once have had and that the possibility of future uncertainty was virtually nonexis- 
A similar pattern can be seen in the Ninth Circuit's decisions on the rights of attorneys to notice and an opportunity to be heard before sanctions are imposed by a trial court. In Miranda $v$ Southern Pacific Transp. Co., ${ }^{165}$ a case in the 1983 sample, fines were imposed on counsel for failure to comply with local rules regarding pretrial conferences. The lawyers argued that the summary nature of the sanction violated their due process rights. Seven years earlier, in In re Allis, ${ }^{168}$ the court had upheld a finding of contempt even though the attorney had been given only ten minutes to prepare his defense. A dissenting judge in Miranda argued that Allis compelled affirmance, ${ }^{167}$ but the majority held that the lawyers had not received adequate notice or opportunity to respond. ${ }^{168} \mathrm{~A}$ later case in the 1983 sample distinguished Allis in reversing a summary contempt conviction;'169 thereafter, Allis was never again cited in the circuit for its procedural holding. ${ }^{170}$ Meanwhile, Miranda be-

tent. However, in an amended opinion issued late in 1988, a panel relied on Steele in finding a violation of equal protection rights in a civil suit. Benigni $v$ City of Hemet, 861 F2d 1092, 1097 (advance sheet) (9th Cir 1988) (Benigni II) (opinion withdrawn from publication). The court acknowledged that it could not "articulate precisely the basis or manner in which the City perceived Benigni causing the City to treat him in a discriminatory manner," id, and for that reason one judge dissented on the equal protection issue, id at 1100 . Curiously, the court's initial opinion had made no mention of Steele; instead, the unanimous panel relied on evidence which it found sufficient to show "discriminatory intent of singling out Benigni based on his Italian ancestry." Benigni $v$ City of Hemet, 853 F2d 1519, 1523 (9th Cir 1988) (Benigni $I$ ). Because the original opinion had been superseded, the amended opinion may well have muddied the distinction between the situations covered by Steele and those covered by precedents like Wayte and Christopher that rejected selective prosecution claims. However, early in 1989 the amended opinion was itself superseded. In the new opinion, the court (again unanimous) deleted the citation to Steele and reinserted the reference to the plaintiff's Italian ancestry. Benigni $v$ City of Hemet, 868 F2d 307, 311 (9th Cir 1989) (Benigni III). Thus Steele can once again be deemed a derelict in the law. (Benigni III was in turn superseded by a revised opinion on June 15, 1989, but the discussion of the equal protection claim remained unchanged, with no mention of Steele.)

165710 F2d 516 (9th Cir 1983).

${ }^{168} 531$ F2d 1391 (9th Cir 1976).

${ }^{367}$ Miranda, 710 F2d at 524-25 (Wallace dissenting).

${ }^{188}$ Although the majority did not explicitly distinguish Allis, the opinion responded to the dissent in a footnote stating that due process requires "a separate hearing addressed to the particular issue of the imposition of sanctions, with notice of the rule violation charged, and an opportunity for the attorneys to respond." Id at $523 \mathrm{n} \mathrm{12.} \mathrm{The} \mathrm{footnote} \mathrm{further}$ described the proceedings in the court below and explained why they fell short of the constitutional standard. I treat this as an implicit distinction of Allis, although I am not convinced that it is both clear and cogent.

${ }^{160}$ United States $v$ Lee, 720 F2d 1049, 1053-54 (9th Cir 1983). The court did not cite Miranda.

${ }^{170}$ It was cited once for a definition of contempt. United States $v$ Metropolitan Disposal Corp., 622 F Supp 1262, 1264-65, 1271 (D Or 1985), aff'd, 798 F2d 1273 (9th Cir 1986) (per curiam). The case did not involve any issues as to the adequacy of the procedures followed by the trial court. 
came a leading authority on the procedures required for imposition of sanctions in the trial court. Several decisions-including one in the 1986 sample-relied on it without mentioning Allis. ${ }^{171}$

When I looked at developments subsequent to the sample cases, I found no instances of disarray or confusion that could be traced to the treatment of a precedent that $I$ had classified as at best supporting for the losing party. This is not to say that the law was invariably clear and predictable. Sometimes existing precedents were themselves ambiguous. ${ }^{172}$ Rules were often couched in open-ended language that required consideration of "the totality of the circumstances"173 or "the special facts of each case."174 Some

171 The case in the 1986 sample was Ford v Alfaro, 785 F2d 835 (9th Cir 1986). The court followed Miranda in holding that the district court abused its discretion in imposing sanctions without giving adequate notice and opportunity to be heard. Id at 840 . However, these errors were held to be harmless. More recently, Miranda was relied on in cases where the imposition of sanctions was reversed. Tom Growney Equipment $v$ Shelley Irrigation, 834 F2d 833, 835-36 (9th Cir 1987); Kirshner v Uniden Corp. of America, 842 F2d 1074, 1082-83 (9th Cir 1988).

${ }^{172}$ For example, in Building Service Employees Pension Trust v Horsemen's Quarter Horse Racing Ass'n, 98 FRD 458, 461 (N D Cal 1983), the parties agreed that Fentron Indus. $v$ National Shopmen Pension Fund, 674 F2d 1300 (9th Cir 1982), was the controlling authority, but they disagreed on the result it dictated. The Building Service Employees court attributed the difficulty to Fentron's failure to delineate clearly between the "injury in fact" requirement and the "zone of interest" requirement for standing under ERISA. Building Service Employees, $98 \mathrm{FRD}$ at 461 . There is no reason to believe that the difficulty would have been exacerbated by the distinction drawn a few weeks later in Associated Builders \& Contractors $v$ Carpenters Vacation \& Holiday Trust Fund, 700 F2d 1269, 1278 (9th Cir 1983), a case in the 1983 sample. On the contrary, Associated Builders might well have clarified Fentron. See Mutual Life Ins. Co. $v$ Yampol, 840 F2d 421, 423 n 2 (7th Cir 1988) (suggesting that Associated Builders "limit[ed] Fentron to confer standing only where 'specific and personal' injuries are alleged"). At this writing no Ninth Circuit case has ever cited Associated Builders.

In Sagebrush Rebellion, Inc. $v$ Watt, 713 F2d 525 (9th Cir 1983), the court held that the district court erred in denying intervention as of right by an environmental organization. A dissenting opinion argued that two cases relied on by the majority, "bereft of any legal analysis on the intervention issue, . . cause problems for subsequent application." Id at 531-32 (Wallace dissenting). But the dissent took no solace from the fact that one of the cases had been distinguished by a decision in the 1983 sample. See Westlands Water Dist. $v$ United States, 700 F2d 561, 563 (9th Cir 1983) (distinguishing Washington State Bldg and Construc. Trades Council v Spellman, 684 F2d 627 (9th Cir 1982)). The majority insisted that "[i]n neither of [the two cases] did this court have any difficulty determining" that the criteria for intervention as of right were met. Sagebrush Rebellion, 713 F2d at 527. But even if one accepts the dissent's view, the "problems for subsequent application" cannot be attributed to the treatment of precedent in Westlands.

173 See, for example, United States v Buffington, 815 F2d 1292, 1300-01 (9th Cir 1987) (stating test for determining whether an arrest has occurred).

${ }^{174}$ See Mahon v NLRB, 808 F2d 1342, 1346 (9th Cir 1987) (describing standard for judicial review of NLRB determinations regarding deference to private agreements). The court noted that the question of deferral to settlement and arbitration "has been a rich source of litigation" in the Ninth Circuit. Id at 1345. Among the cases cited was Airport 
decisions invoked what might be called yin and yang formulations-thrust and parry canons like those made familiar by Karl Llewellyn in the realm of statutory construction. ${ }^{175}$ In a few instances, there was evidence that later decisions had drawn distinctions that might prove difficult to apply. ${ }^{178}$ However, in none of these situations could it be said that the sample case had created a conflict, or even that it had contributed in any substantial way to uncertainty in the law. In that respect, at least, the theory appears to be sound.

\section{Step three cases.}

I found about twenty-five cases in the 1983 sample in which an existing precedent could have been deemed "arguably compelling" for the losing side. However, a few of these were cases in which there were already multiple precedents pointing in different directions. I decided to treat these with the other multiple-precedent cases in order to permit a more accurate estimate of the number of intracircuit conflicts created in the course of a year. ${ }^{177}$

In most of the step three cases, the 1983 panel articulated a distinction that I thought was clear and cogent-one that could be understood and followed even if it was not apparent in the earlier decisions. One such case, EEOC $v$ Crown Zellerbach Corp., has al-

Parking Management v NLRB, 720 F2d 610 (9th Cir 1983).

${ }^{175}$ See Llewellyn, The Common Law Tradition at 522-29 (cited in note 34). For example, opinions in Medicare provider reimbursement cases repeatedly assert that the court will give due deference to the agency's interpretation of a statute or regulation. See, for example, Loma Linda University $v$ Schweiker, 705 F2d 1123, 1126 (9th Cir 1983). That proposition is often paired with the statement that "the deference ... is not total" and that "[t]he interpretation must sensibly conform to the purpose and wording of the regulations." Villa View Community Hosp. $v$ Heckler, 720 F2d 1086, 1090 (9th Cir 1983), quoting Pacific Coast Medical Enterp. $v$ Harris, 633 F2d 123, 131 (9th Cir 1980). Which of these formulations prevails depends on the particular statutes and regulations involved. But neither "rule" can, by itself, control the disposition of a case. Nor can the two rules together.

${ }^{176}$ For example, two district judges thought that Hymen $v$ Merit Systems Protection Board, 799 F2d 1421 (9th Cir 1986), had created a conflict with Rice $v$ Hamilton Air Force Base Commissary, 720 F2d 1082 (9th Cir 1983), a case in the 1983 sample. See Cupp v Veterans Administration Hosp., 677 F Supp 1018, 1020-21 (N D Cal 1987); Hollcroft v Department of the Treasury, $687 \mathrm{~F}$ Supp 510, 515-16 (E D Cal 1988). I do not agree. In Hymen, the court emphasized that none of the papers attached to the complaint named the proper defendant, 799 F2d at 1422, while in Rice at least one paper did. 720 F2d at 1085-86. In any event, whatever confusion may have been generated by Hymen's treatment of Rice cannot be attributed to Rice's treatment of earlier precedents.

173 Where reasonable minds could differ as to whether there were already multiple precedents pointing in different directions, I did not put the case in that category. The reason was to avoid underestimating the number of new conflicts. 
ready been described. ${ }^{178}$ Another example is United States $v$ Moreno-Pulido. ${ }^{179}$ The defendant, convicted of selling blank counterfeited "green card" forms in uncut sheets, argued that uncut sheets are not "counterfeited instruments [or] paper" within the meaning of the statute. ${ }^{180}$ In the earlier case of United States $v$ Johnson, ${ }^{181}$ the court, in reversing another counterfeiting conviction, had stated that "the counterfeit obligation . . . must be sufficiently complete to be an imitation of and to resemble the genuine article."182 The Moreno-Pulido court distinguished Johnson by noting that Johnson involved "a photocopy of one side of a bill, made with 'bad ink' on poor quality pinkish paper," so that the issue "was plainly one of quality of reproduction, not of the completion of the counterfeiting process."183 Johnson itself was ambiguous on this point, ${ }^{184}$ but the distinction articulated in MorenoPulido eliminated the ambiguity in a way that did not create a conflict. ${ }^{185}$

A more questionable distinction was drawn in Davies $v$ Commissioner ${ }^{\mathbf{1 8 6}}$ to support the court's holding that appeals filed by five taxpayers from decisions of the Tax Court were not timely. The taxpayers concededly had not filed notices of appeal within ninety days of the Tax Court decision, as required by statute, but they pointed to a Ninth Circuit precedent, Estate of Lang $v$ Commissioner, ${ }^{187}$ in which the court had allowed a late filing of a notice of appeal. In Davies as in Lang, the taxpayers' cases had been consolidated with a decision in which a timely notice of appeal had been filed; as in Lang, the cases had been decided as a single proceeding. In these circumstances, Lang was an arguably compelling precedent, and indeed a dissenting judge insisted that it was squarely on point. ${ }^{188}$ However, the majority distinguished Lang on two grounds, one of which was that "in Lang, both cases involved

\footnotetext{
178 See text at notes $92-95$.

178695 F2d 1141 (9th Cir 1983).

180 Id at 1143.

181434 F2d 827 (9th Cir 1970).

${ }^{182}$ Id at 830 (emphasis added).

${ }^{183}$ Moreno-Pulido, $695 \mathrm{~F} 2 \mathrm{~d}$ at $1145 \mathrm{n} 7$.

284 See Johnson, 434 F2d at 829.

${ }^{185}$ It may be overstating the resemblance between the two cases even to call Johnson an arguably compelling precedent for Moreno-Pulido, since, among other things, the two cases involved different statutes. However, I classified the case as I did to avoid any tendency to underestimate the number of conflicts.

186715 F2d 435 (9th Cir 1983).

${ }^{187} 613$ F2d 770, 771-72 n 1 (9th Cir 1980).

${ }^{288}$ Davies, 715 F2d at 438-40 (Duniway dissenting).
} 
the same taxpayer, whereas here each case involves different taxpayers."188 Nothing in Lang supported that distinction, and for that reason one can say that it was unfair for the court to impose it retroactively. Nevertheless, it seems to me that the line, once drawn, is both clear cut and in accord with the way similar problems are treated elsewhere in the law. ${ }^{190}$ Thus, from the forward-looking perspective that is relevant in assessing consistency, the court did not create a conflict by distinguishing Lang in the way it did.

Another case in which a dissent accused the majority of flouting a controlling precedent was California $v$ Harvier. ${ }^{101}$ There the court dismissed an appeal for want of jurisdiction by invoking the rule that "[o]rdinarily, an order dismissing a complaint but not the underlying action is not a final order." ${ }^{182}$ A dissenting judge insisted that the case fell within an established exception for situations where it is clear that "the action could not be saved by any amendment of the complaint which the plaintiff could reasonably be expected to make."193 The majority observed that "[a]lmost all the remarks" at the hearing on the motion to dismiss were "ambiguous to some extent," and concluded that the colloquy could not "fairly be construed as 'clearly' demonstrating that the district court determined that no possible amendment could save the complaint."194 There is perhaps an element of paradox in asking whether an opinion has clearly stated that a lower court ruling is not clear. Still, in both of the cases relied on by the dissent, the trial court had been much more explicit in dismissing the complaint than the lower court in Harvier had been. ${ }^{195}$ In any event,

180 Id at 438. The second basis for distinction was that in Lang, the Tax Court had said in its memorandum opinion that "[d]ecision" [singular] will be entered under Rule 155," whereas in Davies the Tax Court had said that "Decisions [plural] will be entered. . .." As the dissenting judge argued, this was a hypertechnical distinction-one that would escape the attention of most lawyers reading the decisions in question.

${ }^{100}$ See, for example, Torres v Oakland Scavenger Co., 108 S Ct 2405 (1988) (failure to name specific individual in notice of appeal deprives court of jurisdiction over that individual's appeal).

191700 F2d 1217 (9th Cir 1983).

102 Id at 1218.

${ }^{103}$ Id at 1220, 1222-23 (Norris dissenting), quoting Marshall $v$ Sawyer, 301 F2d 639, 643 (9th Cir 1962).

194 Harvier, 700 F2d at 1219 (emphasis added).

195 In Marshall, the district court had dismissed the complaint not for failure to state a claim "but on the ground that, whether or not a claim has been stated, the federal court should abstain." 301 F2d at 643 . This meant that there was no way the plaintiff could amend his complaint to avoid dismissal. In Scott v Eversole Mortuary, 522 F2d 1110 (9th Cir 1975), the district judge had explicitly stated that curing "other deficiencies" in the 
subsequent decisions by Ninth Circuit panels have manifested no difficulty in placing cases on one side of the line or the other. ${ }^{196}$ Whether the distinction is equally clear to the bar I do not know, though I would think that any uncertainty in a particular case could be eliminated simply by asking the district court to enter a judgment dismissing the action.

There remain six cases in which the court distinguished an arguably controlling contrary precedent in a way that I could not characterize as clear and cogent. If we extrapolate from the sample, the results would suggest that about thirty such decisions were issued by the Ninth Circuit Court of Appeals in the course of the year. However, the analysis cannot stop there. To question the clarity and cogency of a distinction is not to say that the panel has created a conflict; it is only to say that the panel's decision has a strong potential for doing so. To determine whether the potential has been realized, it is necessary to look at subsequent developments in the law.

I have already described the fate of the contrary precedents invoked in two of these six cases, United States v Al Mudarris ${ }^{197}$ and Miranda $v$ Southern Pacific Transp. Co. ${ }^{198}$ In each instance the earlier precedents have " "been worn away by the erosion of time' ... and of contrary authority." 198 This is not an uncommon phenomenon in the law, although the two cases represent different variants of it: in Al Mudarris, the eroded precedent arose out of an extreme factual situation, while in Miranda it rested on an attitude that proved to be out of step with later views.

Two of the remaining four cases lacking a clear and cogent distinction were reversed on plenary review by the United States Supreme Court. ${ }^{200}$ The Supreme Court also reversed two other

complaint "would not cure the basic problem." Id at $1112 \mathrm{n} 1$. Again, the trial court had made clear that amendment to the complaint could not save the action.

${ }^{198}$ See, for example, Proud v United States, 704 F2d 1099 (9th Cir 1983) (dismissing appeal on the ground that plaintiffs, granted leave to amend complaint by district court, failed to notify district court of their decision not to amend and hence no final judgment had yet been entered); Gerritsen v de la Madrid Hurtado, 819 F2d 1511, 1514-15 (9th Cir 1987) (accepting jurisdiction since district court had made clear that complaint could not properly have been amended to state a cause of action).

${ }^{197} 695$ F2d 1182 (9th Cir 1983) (discussed in text at notes 160-64).

${ }^{198} 710$ F2d 516 (9th Cir 1983) (discussed in text at notes 165-71).

199 United States $v$ Raines, 362 US 17, 25-26 (1960) (citations omitted) (describing fate of Barney $v$ City of New York, 193 US 430 (1904)).

${ }^{200}$ See Shelter Framing Corp. v Pension Benefit Guaranty Corp., 705 F2d 1502 (9th Cir 1983), rev'd as Pension Benefit Guaranty Corp. v. R. A. Gray \& Co., 467 US 717 (1984); United States v Miller, 715 F2d 1360 (9th Cir 1983), amended, 728 F2d 1269 (9th Cir 1984), rev'd, 471 US 130 (1985). In Shelter Framing, the court described Todd Shipyards Corp. $v$ 
cases in which the losing party relied on an arguably controlling Ninth Circuit precedent, albeit one that the panel adequately distinguished. ${ }^{201}$ Only one other case in the sample was reversed by the Supreme Court. ${ }^{202}$ Although caution must be used in drawing conclusions on the basis of such a small number, the results suggest that decisions that depart substantially from the dominant thrust of circuit precedent may also be aberrant from a national perspective. ${ }^{203}$ As the cases in the sample demonstrate, such decisions are not likely to retain their authority for long.

In the remaining two cases, the treatment of precedent left a residue of uncertainty in the law that as of 1988 had not dissipated. Frakes $v$ Pierce ${ }^{204}$ created an uneasy duality between cases allowing judicial review of federal agency decisions under the $\mathrm{Na}$ tional Housing Act $^{20 r}$ and cases prohibiting such review because

Witthun, 596 F2d 899 (9th Cir 1979), as a case which had upheld a statutory scheme similar to the one before it, but the opinion did not explain why the latter called for a different result. Shelter Framing, $705 \mathrm{~F} 2 \mathrm{~d}$ at $1513 \mathrm{n} 11$. In Miller, the panel amended the opinion to state that the defendant had been convicted for "a substantially different scheme from that pleaded in the indictment" rather than for a "narrower scheme," as the original opinion had declared. Compare Miller I, 715 F2d at 1363, with Miller II, 728 F2d at 1270 (emphasis added). However, the panel left unaltered the extended discussion in the original opinion emphasizing that the government had proved only one of two elements of the scheme charged by the grand jury. See Miller I, 715 F2d at 1362. That circumstance seemed to bring the case squarely within the rationale of earlier decisions holding that "[i]n a mail fraud prosecution, . . . the Government need not prove every misrepresentation charged conjunctively in the indictment." See United States $v$ Halbert, 640 F2d 1000, 1008 (9th Cir 1981).

${ }^{201}$ See United States $v$ Albertini, 710 F2d 1410, 1417 (9th Cir 1983) (distinguishing both United States v Douglass, 579 F2d 545 (9th Cir 1978), and United States v May, 622 F2d 1000 (9th Cir 1980)), rev'd, 472 US 675 (1985); and Pacific Stationery \& Printing Co. $v$ Northwest Wholesale Stationers, Inc., 715 F2d 1393, 1395-96 (9th Cir 1983) (distinguishing both Joseph E. Seagram \& Sons, Inc. v Hawaiian Oke \& Liquors, Ltd., 416 F2d 71 (9th Cir 1969), and Ron Tonkin Gran Turismo, Inc. v Fiat Distributors, Inc., 637 F2d 1376 (9th Cir 1981)), rev'd, 472 US 284 (1985).

${ }^{202}$ Rutherford $v$ Pitchess, 710 F2d 572 (9th Cir 1983), rev'd as, Block v Rutherford 468 US 576 (1984). Another case in which the Ninth Circuit panel distinguished contrary (but not arguably compelling) precedents was called into question when the Supreme Court reversed a later Ninth Circuit panel that had relied on the case in the sample. Compare United States v Quintero-Castro, 705 F2d 1099 (9th Cir 1983), with United States v Montoya de Hernandez, 473 US 531, 536 (1985), rev'g, 731 F2d 1369 (9th Cir 1984). However, the Supreme Court in Montoya de Hernandez addressed only the legal standard for detaining a traveller at the border; it did not decide what level of suspicion is required for $x$-ray and body cavity searches, which was the specific issue considered in Quintero-Castro. See 473 US at $541 \mathrm{n} 4$.

${ }^{203}$ Of the four Supreme Court reversals, three were unanimous. The only exception was United States v Albertini, 472 US 675 (1985).

204700 F2d 501 (9th Cir 1983).

${ }^{205}$ The strongest precedent at the time of Frakes was Russell $v$ Landrieu, 621 F2d 1037, 1041-42 (9th Cir 1980) (holding that if the Secretary, in disposing of property, "failed 
"there is no law to apply." arise very often. ${ }^{207}$ Finally, Broadway Cab Cooperative, Inc. $v$ Teamsters ${ }^{208}$ left open the extent to which courts that are asked to enforce arbitrators' awards are permitted to review legal issues de novo rather than with the deference usually accorded arbitrators' decisions. ${ }^{209}$ Four years later, another panel recognized that the scope of the exception was "not clearly defined"210 _ an observation made more pointed by the fact that district court had relied on Broadway $\mathrm{Cab}$ in reviewing de novo "that part of the [arbitrator's] decision which [was] alleged to be contrary to law and public policy."211 The court of appeals reversed the district court and thereby cast doubt on the continuing vitality of Broadway $\mathrm{Cab}{ }^{212}$

Unfortunately from the standpoint of research, these histories provide a dubious base from which to estimate the total number of intracircuit conflicts created by panel decisions in the course of the year. The subset of cases is so small, and the outcomes so varied, that any attempt to extrapolate would be attended by a high margin of error. But this does not mean that no conclusions can be drawn from the data. On the contrary, perhaps the most significant finding is that in all but two of the cases the uncertainty created by the panel decisions had been largely if not entirely dissipated within three years.

\section{Multiple-precedent issues.}

Twelve cases in the 1983 sample involved issues that had al-

to consider and implement alternatives which would have enabled him to effect the policies and objectives of the National Housing Act," judicial relief would be appropriate).

${ }^{208}$ Frakes, 700 F2d at 505, quoting Citizens to Preserve Overton Park v Volpe, 401 US 402,410 (1971).

${ }^{207}$ I found only two post-Frakes decisions addressing the availability of judicial review of HUD decisions, and both found review available. Clary $v$ Mabee, 709 F2d 1307 (9th Cir 1983); Walker v Pierce, 665 F Supp 831 (N D Cal 1987). In Clary, one judge (a member of the panel in Frakes) rejected the majority's position on reviewability. See Clary, 709 F2d at 1310 (Wallace concurring).

${ }^{203} 710$ F2d 1379 (9th Cir 1983).

209 The court acknowledged precedents requiring deference "not only to an arbitrator's factual determinations, but ordinarily to his legal conclusions as well." Id at 1382 . However, the panel agreed with the employer that de novo review was appropriate on the issue of estoppel. Id.

${ }_{210}$ Northrop Corp. v Triad Int'l Marketing S.A., 811 F2d 1265, 1269 n 6 (9th Cir 1987).

${ }^{211}$ Northrop Corp. $v$ Triad Financial Establishment, 593 F Supp 928, 936 n 14 (C D Cal 1984), rev'd, 811 F2d 1265 (9th Cir 1987).

212811 F2d at 1269. A Supreme Court decision in late 1987 reaffirmed the general policy of deference to arbitrators' decisions but did not explicitly address the possibility of an exception for some "legal" issues. United Paperworkers Int'l Union v Misco, Inc., $108 \mathrm{~S} \mathrm{Ct}$ 364 (1987). 
ready generated multiple precedents pointing in both directions. I placed these cases in a separate category for two reasons. ${ }^{213}$ First, since one of the purposes of the study was to quantify the extent of intracircuit conflict, it would have been misleading to attribute to the 1983 sample an inconsistency created by earlier decisions. Second, even where the three-part test would not necessarily lead to the conclusion that a conflict existed, the need to reconcile multiple precedents itself places a burden on judges and lawyers that must be taken into account in evaluating the workability of the large appellate court. ${ }^{214}$

Not surprisingly, there was some duplication of issues within the sample. Four decisions considered appeals by aliens seeking to avoid deportation on the ground of extreme hardship. ${ }^{215}$ As of 1983, claims of this kind-often raised in the context of a motion to reopen deportation proceedings-had been generating disarray among Ninth Circuit panels for at least five years. ${ }^{216}$ An en banc decision in 1980 did not end the tug-of-war, nor did its summary reversal by the Supreme Court. ${ }^{217}$ Ultimately the issue disappeared

${ }^{213}$ The category does not include cases where the precedents, although numerous, pointed strongly in one direction. In that situation, the large volume of decisions does not contribute to uncertainty. A good illustration is severance in criminal prosecutions: although there are many cases on the books, I found only one after 1980 in which the court of appeals held that the trial court had abused its discretion in denying a severance motion. See United States v Lewis, 787 F2d 1318, 1320-23 (9th Cir 1986).

The category also excludes cases presenting issues that did not generate a large volume of precedents until after 1983. See, for example, Twentieth Century-Fox v MCA, Inc., 715 F2d 1327 (9th Cir 1983) (issue of substantial similarity in copyright case).

216 At the same time, the analysis assumes at least a modest level of care in defining the "issue" in a case, so that the category does not swallow the entire scheme. The point is illustrated by United States v Perez-Reveles, 715 F2d 1348 (9th Cir 1983), a decision interpreting the "ends of justice" exclusion in the Speedy Trial Act. The court held that the Act was violated, but based its holding on the lower court's failure to provide an explicit statement of reasons for granting a continuance. Id at 1350-53. The case thus stands apart from precedents construing the substance of the "ends of justice" exclusion. I do not think it is unreasonable to expect lawyers and judges to recognize such distinctions.

${ }^{215}$ Ramirez-Gonzalez v INS, 695 F2d 1208 (9th Cir 1983); Agustin v INS, 700 F2d 564 (9th Cir 1983); Israel $v$ INS, 710 F2d 601 (9th Cir 1983); Hyun Joon Chung $v$ INS, 720 F2d 1471 (9th Cir 1983). Against the odds, all four of these cases affirmed the Board of Immigration Appeals. The total number of published decisions on this issue in 1983 was seven; the other three found in favor of the alien. See De la Luz v INS, 713 F2d 545 (9th Cir 1983); Contreras-Buenfil v INS, 712 F2d 401 (9th Cir 1983); Batoon v INS, 707 F2d 399 (9th Cir 1983). All three relied on Santana-Figueroa v INS, 644 F2d 1354 (9th Cir 1981). SantanaFigueroa was distinguished in one of the four cases in the 1983 sample, see Ramirez-Gonzales, 695 F2d at 1211-12; it was not even mentioned in the other three.

${ }^{216}$ For an account of this confusion, see Urbano de Malaluan v INS, 577 F2d 589, 596 (9th Cir 1978) (Kennedy dissenting).

${ }^{217}$ Wang v INS, 622 F2d 1341 (9th Cir 1980), rev'd, 450 US 139 (1981) (per curiam). Compare, for example, Prapavat v INS, 662 F2d 561 (9th Cir 1981) (per curiam) (reversing 
from the Federal Reporter, presumably because of the amnesty provisions enacted by Congress in the Immigration Reform and Control Act of $1986 .{ }^{218}$

An issue that has been generating precedential confusion in the Ninth Circuit for even longer than "extreme hardship" is the standard for judging claims of attempted monopolization under $\S 2$ of the Sherman Act. ${ }^{219}$ Claims of this kind were raised in two cases in the 1983 sample. In both cases the district court had granted summary judgment for the defendant; on appeal, one panel reversed, ${ }^{220}$ the other affirmed. ${ }^{221}$ Although subsequent opinions have evidenced continuing disagreement over the elements of a $\S 2$ attempt claim, ${ }^{222}$ there is some evidence that in recent years the law has finally begun to stabilize. ${ }^{223}$

Board of Immigration Appeals), with Hee Yung Ahn v INS, 651 F2d 1285 (9th Cir 1981) (affirming Board of Immigration Appeals). In Hee Yung Ahn, the court acknowledged decisions that had reversed the Board, but blandly asserted that the cases were "not the sort of precedent[s] we are bound to follow." 651 F2d at 1287 n 1. Prapavat in turn distinguished Hee Yung Ahn. Prapavat, 662 F2d at 562 n *. In 1985, the Supreme Court again emphasized the narrow scope of judicial review of Board determinations denying reopening, see INS $v$ Rios-Pineda, 471 US 444 (1985), but the disarray in the Ninth Circuit continued. The government sought en banc review, arguing that "the applicable law in this Circuit remains uncertain, the Board and immigration judges are left under conflicting directives, and the consequent confusion has engendered more and more litigation." Motion to Consolidate for En Banc Hearing in Fuentes $v$ INS (Dkt No 83-7662) [and five other cases] at 3 (filed Sept 11,1985 ) (on file with the author). Nevertheless, en banc rehearing was denied, see Saldana $v$ INS, 793 F2d 222 (9th Cir 1986) (Sneed dissenting), and decisions continued to come down on both sides of the line. Compare, for example, Jara-Navarrette v INS, 813 F2d 1340 (9th Cir 1986) (upholding alien's claim), with Ramirez-Durazo v INS, 794 F2d 491 (9th Cir 1986) (rejecting claim).

${ }_{218}$ Immigration Reform and Control Act of 1986, Pub L No 99-603, 100 Stat 3394, codified at 8 USC $\S 1101$, et seq (Supp 1986). A WESTLAW search on May 10, 1989, found only one Ninth Circuit case on extreme hardship after December 31,1987, an unpublished affirmance of the BIA. Espinoza-Muruato v INS, 845 F2d 1029 (9th Cir 1988) (table).

${ }^{210}$ See Daniel J. Gifford, The Role of the Ninth Circuit in the Development of the Law of Attempt to Monopolize, 61 Notre Dame Lawyer 1021 (1986).

${ }_{220}$ Northrop Corp. v McDonnell Douglas Corp., 705 F2d 1030, 1057-58 (9th Cir 1983).

${ }^{221}$ Cascade Cabinet Co. $v$ Western Cabinet \& Millwork Inc., 710 F2d 1366, 1373-74 (9th Cir 1983).

${ }^{222}$ See, for example, Marsann Co. $v$ Brammall, Inc., 788 F2d 611, 615-16 (9th Cir 1986) (Choy concurring in reversal of summary judgment for defendant) (disputing majority's interpretation of Ninth Circuit precedents); Syufy Enterprises v American Multicinema, Inc., 793 F2d 990, 999 n 13 (9th Cir 1986) (acknowledging "a measure of confusion" on whether dangerous probability of success continues to be a necessary element of an attempt claim).

${ }^{223}$ I found no case after 1986 in which the Ninth Circuit upheld a claim of attempted monopolization, and several that rejected such claims. See, for example, Rutman Wine Co. $v$ E. \& J. Gallo Winery, 829 F2d 729, 736 (9th Cir 1987); Christofferson Dairy, Inc. v MMM Sales, Inc., 849 F2d 1168, 1174-75 (9th Cir 1988). In two antitrust cases that were hotly contested on other issues, the plaintiffs did not pursue their claims under $\S 2$. See Ferguson $v$ Greater Pocatello Chamber of Commerce, Inc., 848 F2d 976, 984 (9th Cir 1988) (noting that plaintiffs did "not seriously question" the district court's rejection of their $\S 2$ claims); 
Four of the multiple-precedent cases arose out of criminal proceedings. ${ }^{24}$ All but one turned on fact-specific legal rules that by their nature require case-by-case interpretation. ${ }^{225}$ The most extreme manifestation of this phenomenon was United States $v$ Layton, ${ }^{226}$ a conspiracy prosecution in which the government sought to introduce certain statements under the co-conspirator exception to the hearsay rule. The district court excluded the evidence on the ground that the statements had not been made "in furtherance of" the conspiracy, but the court of appeals reversed. ${ }^{227}$ The opinion cited at least nine cases in which the Ninth Circuit had interpreted the "in furtherance of" requirement, and analyzed several of the decisions at length to show how the definition had been applied. ${ }^{228}$ In the years since Layton, additional precedents have been generated on this issue, some finding the disputed statements to be "in furtherance of" the conspiracy, some holding otherwise. ${ }^{229}$

Similar patterns can be seen in the realm of civil litigation. Hedrick $v$ Daiko Shoji Co. $^{230}$ presented the familiar question whether a nondomiciliary defendant was subject to in personam jurisdiction. After reviewing a "partial list of seven factors pertinent to the reasonableness inquiry," the court of appeals reversed the district court's judgment of dismissal. The opinion cited five Ninth Circuit precedents, three upholding the exercise of jurisdiction and two rejecting it. Challenges to territorial jurisdiction also generated two decisions in the 1986 sample. $^{231}$ By that time, at

USA Petroleum Co. $v$ Atlantic Richfield Co., 859 F2d 687, 698 (9th Cir 1988) (noting that plaintiffs voluntarily dismissed their $\S 2$ claim).

224 United States $v$ Layton, 720 F2d 548 (9th Cir 1983) (discussed in text at notes 22629); United States v Christopher, 700 F2d 1253, 1257 (9th Cir 1983) (challenge to an indictment on the ground that it failed to specify the details of the offense charged); United States $v$ Cowley, 720 F2d 1037, 1043 (9th Cir 1983) (perjury prosecution in which the defendant argued that the questions set forth in the indictment were too ambiguous to provide the necessary "stark contrast between the allegedly perjurious statements and the truth allegations."); United States v DeBright, 710 F2d 1404 (9th Cir 1983) (discussed in text at notes 234-36).

${ }^{225}$ The exception is DeBright (discussed in text at notes 234-36).

228720 F2d 548 (9th Cir 1983).

227 Id at 555-56.

${ }^{228}$ Id at 556-58. The opinion noted that "courts sometimes focus on the speaker's intent in making the statements and sometimes on their probable effect. . . . The relationship between these two analyses is unclear." 720 F2d at $556 \mathrm{n} 5$.

229 See, for example, United States $v$ Andersson, 813 F2d 1450, 1456 (9th Cir 1987) (in furtherance); United States v Bibbero, 749 F2d 581, 583-84 (9th Cir 1984) (not in furtherance); United States $v$ O'Connor, 737 F2d 814, 820-21 (9th Cir 1984) (not in furtherance, but harmless error).

${ }^{230} 715$ F2d 1355 (9th Cir 1983).

${ }^{231}$ Hirsch v Blue Cross, Blue Shield of Kansas City, 800 F2d 1474 (9th Cir 1986); 
least nine additional Ninth Circuit precedents had been added to the line. ${ }^{232}$ At this writing, no end is in sight. ${ }^{233}$

Two of the sample cases in which existing precedents pointed in different directions did not involve applications of fact-specific legal rules; on the contrary, the scope of appellate review was itself the subject of dispute. United States $v$ DeBright ${ }^{234}$ raised the question of how the court should apply the concurrent sentence doctrine. Most cases invoking the doctrine had affirmed the conviction on the unreviewed counts, but in the one case where the issue of the appropriate disposition was explicitly considered, the court vacated the conviction. ${ }^{235}$ The DeBright panel opted for the latter approach; however, the opinion alerted the full court to the inconsistency, and rehearing en banc was granted. ${ }^{236}$

No such resolution followed Taylor-Edwards Warehouse and Transfer Co. $v$ Burlington Northern, Inc. ${ }^{237}$ in which the court blurred an apparent inconsistency in Ninth Circuit precedents delineating the scope of review in cases involving contract interpretation. ${ }^{238}$ Taylor-Edwards itself drew a distinction between "the interpretation of the words [of the contract] in light of [the] circumstances," a freely reviewable question of law, and a decision relying on "extrinsic evidence" to interpret an ambiguous contract, a factual determination reversible only for clear error. ${ }^{239}$ Later cases have inclined toward the freely reviewable standard, but the cases continue to articulate the distinction stated in TaylorEdwards. ${ }^{240}$

Decker Coal Co. v Commonwealth Edison Co., 805 F2d 834 (9th Cir 1986).

${ }^{232}$ Curiousiy, Decker Coal cited three cases that were not mentioned in Hirsch, although they were on the books at the time.

${ }^{233}$ As mentioned, a 1988 decision invoked fourteen circuit precedents. See Sinatra v National Enquirer, Inc., 854 F2d 1191 (9th Cir 1988) (discussed in text at note 122). The opinion did not cite Hedrick, probably because the "stream of commerce" rationale of Hedrick was rejected by a plurality of the Supreme Court in Asahi Metal Indus. v Superior Court, 480 US 102 (1987). See Sinatra, 854 F2d at 1196 in 5.

234710 F2d 1404 (9th Cir 1983).

${ }^{235}$ United States $v$ Fishbein, 446 F2d 1201, 1205 (9th Cir 1971).

${ }^{236}$ On rehearing en banc, the court abandoned the rule altogether. United States $v$ DeBright, 730 F2d 1255, 1256 (9th Cir 1984).

237 715 F2d 1330 (9th Cir 1983).

${ }^{238}$ The apparent inconsistency was noted in one of the cases cited in Taylor-Edwards. See Culinary and Service Employees Union v Hawaii Employee Benefit Admin., 688 F2d 1228, 1230 n 1 (9th Cir 1982).

230 Taylor-Edwards, 715 F2d at 1333, 1338.

${ }^{240}$ See Hanson v Prudential Ins. Co., 783 F2d 762, 764 (9th Cir 1985). 


\section{Conclusion}

In a survey conducted for the Ninth Circuit Judicial Conference in 1987, more than half of the lawyers responding expressed the view that the Court of Appeals had not succeeded in avoiding inconsistent decisions by panels considering the same issue. ${ }^{241}$ The results of this study suggest that this perception may have been skewed by the high visibility of several areas of the law in which disarray has persisted over a long period of time. Prominent examples are found in immigration law (particularly issues of political asylum ${ }^{242}$ and "extreme hardship" as a ground for relief from deportation), in Social Security disability cases (especially those involving the weight and credibility of medical evidence), ${ }^{243}$ and in antitrust law (most notably, the question of attempted monopolization under $\S 2$ of the Sherman Act).

For the most part, the present study tends to support the widely shared perception of disarray on these questions. Indeed, it is not by happenstance that the areas of high visibility correlate closely with the multiple-precedent issues discussed in the preceding section. While careful examination might reveal that many of the cases could be classified in discrete subcategories in which the decisions are consistent, the effort required is greater than can be reasonably expected of busy lawyers and trial judges.

At the same time, the study suggests that the confusion found in these areas is not characteristic of Ninth Circuit jurisprudence generally. Nor is intracircuit conflict. To recapitulate: in the 1983 sample, nearly half of the cases did not cite any contrary precedents. When contrary precedents did exist, they were usually no more than supporting for the losing party. And when the losing party could cite arguably compelling precedents, the panel generally succeeded in distinguishing them in a way that avoided conflict for the future.

How significant, then, are the multiple-precedent issues? Several observations are suggested by the data. First, the multiple precedent issues tend to be concentrated in areas of the law where

24 See note 9.

242 Asylum cases did not begin to proliferate until the mid-1980's. As it happens, only two turned up in the $\mathbf{1 9 8 6}$ sample, although fourteen decisions on the issue were published in the course of the year.

24s In a period of only three years in the mid-1980's the Court published fifteen opinions on the weight and credibility of subjective testimony on levels of pain in Social Security disability cases, and nearly as many on the weight to be given to the testimony of the treating physician. 
legal rules do not directly influence the structuring of transactions or other primary activity. Probably this is no coincidence; although fact-specific legal rules have their costs even in a purely procedural setting, they are far more disruptive in the context of planning or negotiation. ${ }^{244}$

Second, many of the rules incorporate great deference to firstline decision makers. At the appellate level, the bulk of cases can be resolved without the need to examine the full range of the court's jurisprudence in the area. Admittedly, the deferential standard of review does not ease the burden on lawyers and adjudicators in the trial courts and agencies. Yet even in the lower courts, it is likely that extended exegesis and comparison will be required only in close or difficult cases like Layton. ${ }^{245}$

Third, disarray in judicial decisions may reflect tensions outside the court system. Litigation over Social Security disability claims proliferated in part because the Reagan administration sought too zealously to purge malingerers from the relief rolls. ${ }^{246}$ Asylum claims cause disagreement in part because of underlying controversy over United States policy in central America.

Fourth, the confusion caused by the existence of multiple relevant precedents eventually yields to a dominant trend or to some outside force. One reason the extreme hardship and attempted monopolization cases have attracted so much attention is that the judicial battles went on for an unusually long time. In contrast, the uncertainty over the scope of a union's duty of fair representation has now been largely resolved. ${ }^{247}$ And the Immigration Reform and Control Act appears to have stemmed the flood of decisions involving asylum as well as extreme hardship. ${ }^{248}$

Finally, it is not clear to what extent uncertainty is inherent in fact-specific legal rules, and to what extent it is exacerbated by the

${ }^{244}$ See Erwin N. Griswold, The Supreme Court, 1959 Term-Foreword: Of Time and Attitudes-Professor Hart and Judge Arnold, 74 Harv L Rev 81, 89 (1960) (urging courts to provide "guidance [that] will enable administrative officers and counsel advising clients to resolve many of the problems long before they develop into disputes or litigation.").

${ }^{245}$ See text at notes 226-29. In Layton, the court, although applying the "abuse of discretion" standard, reversed a ruling by a highly respected district judge.

${ }^{248}$ See Note, Social Security Administration in Crisis: Non-Acquiescence and Social Insecurity, 52 Brooklyn L Rev 89 (1986).

${ }^{247}$ The turning point came in Peterson $v$ Kennedy, 771 F2d 1244 (9th Cir 1985), which the court later characterized as having "attempted to synthesize the various standards set forth in previous cases." Galindo v Stoody Co., 793 F2d 1502, 1514 (9th Cir 1986).

${ }^{248}$ 'Two cases in which en banc review was granted were dismissed after the petitioners' status was adjusted under the new law. See Fuentes $v$ INS, 844 F2d 699 (9th Cir 1988) (en banc); Arguelles-Vasquez v INS, 844 F2d 700 (9th Cir 1988) (en banc) See also note 218. 
large volume of precedents that will be found only in the large court. On this question, intercircuit comparison would certainly be helpful. Do lawyers in the Fifth Circuit have an easier time predicting the outcome of asylum or disability or monopolization cases? It should not be too difficult to find out.

\section{Conclusions and Implications}

\section{A. Inconsistency and "the Luck of the Draw"}

Neither the three-step test nor the empirical study addresses the concern expressed by some lawyers in the Ninth Circuit that the result in the court of appeals will often depend on the composition of the panel that hears the case. This is not because the phenomenon does not exist; even the court of appeals judges will agree that it does. And it is understandable that lawyers would feel uncomfortable with what appears to be an element of lottery in appellate outcomes. Nevertheless, I think that their concern is misplaced.

First, any study that concentrates on published appellate decisions inevitably overstates the extent to which the law is unstable or uncertain. In the familiar metaphor, cases decided by published opinions stand at the apex of a much larger pyramid. For the vast majority of transactions and disputes, the law provides sufficient guidance so that no rational person would think of going to court at all. Of the disputes that do wind up in court, many, perhaps most, involve the application of settled law to particular facts, so that litigation ends at the trial level. Even among the cases that are appealed, more than half are decided by unpublished opinions because they raise no new legal issues.

Second, it is important not to equate uncertainty with inconsistency. Inconsistency does lead to uncertainty, but uncertainty may have many other causes. In particular, the legal consequences of primary conduct may be unpredictable not because the precedents point in different directions, but because there are no precedents closely on point. For example, the result may depend on the interpretation of a statute not previously construed. The Supreme Court may have recently handed down a decision that sets the law on a new course. The facts may bear little resemblance to those of cases already on the books. Or the facts may fall squarely between those of existing precedents. In situations like these, the outcome may well depend on the predilections of the panel that happens to hear the case. But there is no reason to expect that unpredictability of this kind would be more common in the larger circuit. In- 
deed, the larger circuit will probably have a larger number of precedents relevant to any given issue, and that in turn might actually reduce the proportion of cases in which the panel has freedom to decide either way without creating a conflict. ${ }^{249}$

Yet even if that proposition is accepted, it does not fully address concerns about "the luck of the draw," for there remains the argument that aberrant decisions (as distinguished from decisions that create conflicts) will be more readily corrected through en banc rehearing in the small circuit than in the large circuit. Two responses are in order. First, the argument assumes that judges are predictable, even knee-jerk, in their responses to novel issues. That has not been the experience of the federal courts in the last few years, even after eight years of appointments by an administration more concerned with ideology than most. ${ }^{250}$ Thus, where the outcome is uncertain because of the absence of closely relevant precedents, en banc rehearing will not necessarily add to predictability. Second, even judges with strong views about substantive issues will temper them in recognition of the institutional harm that would result from treating panel decisions as merely provisional pending consideration by an en banc court. Especially when one considers the shifts in national political power that have characterized the twentieth century, the system would break down if judges were not willing to live with decisions that they would not have rendered had they been on the panel. ${ }^{251}$

Finally, I believe that much of the concern about unpredictability in a large court of appeals rests ultimately on an impatience with the case-by-case mode of adjudication that is the essence of our common law system. But over the years, our society has concluded that that approach, with all its open-endedness, is prefera-

249 I say "might" because the doubtful situations do not divide neatly into two groups, one with conflicting precedents and one without any precedents very closely on point. The wide spectrum of possible precedential settings is another reason for concentrating on inconsistency rather than examining all sources of unpredictability.

${ }^{230}$ See Michael E. Solimine, Ideology and En Banc Review, 67 NC L Rev 29, 62-64 (1988).

281 This willingness was dramatically demonstrated early in the history of the enlarged Ninth Circuit. In July 1980, while the limited en banc rule was in the final stages of consideration, the judges voted to deny rehearing by the full court of an en banc case submitted before any of the new judges had taken their seats. See United States v Penn, 647 F2d 876, 889 (9th Cir 1980) (Fletcher dissenting from denial of rehearing en banc). The five-four decision generated deep emotions, and almost certainly would have been reversed if the full court had heard the case. Under these circumstances, the denial of further review signified a genuine commitment on the part of the judges to the principle underlying the new rule: a willingness to accept decisions with which they disagreed made by a minority within the court. 
ble to the more structured regime of codification, especially in view of the availability of the legislative deus ex machina whenever disarray or lacunae in decisional law become too much to bear. For that reason as well as the others, I think it is sound to concentrate on inconsistency, which I agree reflects a malfunction in the system, and not to worry overmuch about unpredictability, which is to a large extent unavoidable.

\section{B. Implications for the Future of the Federal Appellate System}

At the beginning of this article, I suggested that the Ninth Circuit's efforts to maintain consistency in the law of the circuit deserve attention in part because the development of large geographically organized appellate courts may provide an alternative to more radical structural reforms in the federal system. Yet in assessing the results of the study, it is necessary to keep in mind some important limitations.

First, as noted earlier, I have made no effort to investigate possible conflicts in unpublished opinions. From the standpoint of lawyers and district courts any such conflicts would be irrelevant because unpublished opinions cannot be cited as precedent. But they would be troublesome from the standpoint of the court's obligation to treat like cases alike-the more so since the profession has no way of monitoring this aspect of the court's work. Thus, it would be a good idea for someone to take a look at the unpublished opinions. ${ }^{252}$

Second, the method of the study may not have been adequate to uncover all multiple-precedent issues, a problem exacerbated by the fact that the 1986 sample has been only partially examined. If a sample case cited only one or two of a larger number of apparently relevant precedents, and if those cases in turn did not lead to many others, I might well have underestimated the extent to which the issue had generated reported decisions. On the other hand, this pattern might indicate only that the sample case did involve a discrete subissue as to which the law was reasonably clear. ${ }^{253}$ In a future article I plan to look at a wider range of published materials; I will also draw upon comments offered in response to a survey I conducted of members of the Ninth Circuit Judicial Conference

\footnotetext{
252 For a critical (but impressionistic) study of the court's practice more than a decade ago, see James N. Gardner, Ninth Circuit's Unpublished Opinions: Denial of Equal Justice?, 61 ABA J 1224 (1975).

${ }^{253}$ For an illustration of the latter situation, see United States $v$ Perez-Reveles, 715 F2d 1348 (9th Cir 1983) (discussed in note 214).
} 
late in 1988. And, of course, I will be able to cross-check the research results for the two sample years.

Third, even if the study could provide complete data on the incidence of intracircuit conflicts, there would still be room for disagreement over the degree of freedom that panels ought to have in treating existing precedents. As with intercircuit conflicts, variations in approach that would be seen by some as nothing more than the common law "work[ing] itself pure from case to case"254 will be regarded by others as creating an undesirable level of uncertainty and unpredictability.

Fourth, the study cannot quantify the hidden costs of maintaining consistency in the large circuit: the additional burdens on judges that will not be reflected in their published work. Members of the court acknowledge that they spend a substantial amount of time reviewing opinions and exchanging memoranda in order to iron out apparent inconsistencies without calling an en banc hearing. Thus far, however, there is little evidence to suggest that these efforts have interfered with the judges' productivity. ${ }^{255}$

Finally, evaluation of the findings of this study must be comparative, not absolute. Whatever the inadequacies of the Ninth Circuit's efforts to maintain a consistent law, and whatever the costs of those efforts, both must be weighed against the costs of alternative solutions to the "crisis of volume" in the federal appellate system. Occasional inconsistencies in panel decisions may be a small price to pay when judged against the likely consequences of establishing specialized appellate courts-fragmentation of the law, tunnel vision, interest group dominated appointments, and centralization of power. And if the alternative is the establishment

${ }^{204}$ Graham Hughes, Are Justices Just?, NY Rev Books 41, 42 (Nov 19, 1981) (quoting Lord Mansfield). This is not quite what Lord Mansfield said, see Omychund v Barker, 1 Atk 21, 33, 26 Eng Rep 15, 23 (1744), but I prefer Hughes's version.

${ }^{265}$ It is true that in recent years the Ninth Circuit has ranked low among the twelve regional circuits in the number of appeals terminated on the merits per three judge panel. See, for example, 1988 Annual Report at 21 (cited in note 7). The court has also had one of the poorest records for speed of case processing, if one measures the median time from filing notice of appeal to disposition. However, the court comes off quite favorably in the size of its backlog, as measured by the number of appeals pending per panel. Similarly, if one looks at the median time for processing cases after the judges have begun work, the Ninth Circuit looks quite good. Perhaps the judges on other courts of appeals handle more cases individually because those courts do not have as many judgeships as their caseloads would warrant.

Even if one were to focus solely on the Ninth Circuit's modest showing in the statistical data on case participations per judge, it would be impossible to identify a cause and effect relationship because so many other factors may also be at work (for example, the Ninth Circuit's practice of writing self-contained memoranda in cases not decided by published opinion). 
of a national court of appeals, with possibly devastating effects on the Supreme Court's performance of its essential functions, ${ }^{256}$ the large circuit may look almost benign.

${ }^{258}$ See Arthur D. Hellman, Preserving the Essential Role of the Supreme Court: A Comment on Justice Rehnquist's Proposal, 14 Fla St U L Rev 15 (1986). 
